\title{
Türkçe Öğretmeni Adaylarının Dijital Öyküleme Sürecine İlişkin Görüşleri ve Algıları*
}

\section{Opinions and Perceptions of Prospective Turkish Teachers Related to the Digital Storytelling Process}

\author{
Veysel DEMİRER ${ }^{* *} \quad$ Yasemin BAKİ $^{* * *}$
}

Received: 09 February 2018

Research Article

Accepted: 27 August 2018

\begin{abstract}
In this research, it is aimed to investigate the opinions and perceptions of prospective Turkish teachers about digital storytelling process. In the study, case study design was used. The study group was determined through convenience sampling from purposeful sampling methods and it consisted of 35 prospective teachers at Recep Tayyip Erdoğan University, Department of Turkish Language Teaching. The Metaphor Identification Form was used to identify the perceptions of prospective teachers related to digital stories and the "Semi-structured Interview Form" was used to determine their opinions about digital storytelling process. The data for student views were analyzed through descriptive analysis and metaphors were analyzed by content analysis. As a result of the research, it was determined that the digital storytelling process mostly improved the writing, technology and speaking skills of prospective Turkish teachers. It was also found that prospective Turkish teachers perceived digital stories as a fun, gripping and reflective tool.
\end{abstract}

Keywords: Turkish teacher candidates, digital storytelling, perception and opinions.

ÖZ: Bu araştırmada, Türkçe öğretmeni adaylarının dijital öyküleme sürecine ilişkin görüşlerinin ve algılarının incelenmesi amaçlanmıştır. Araştırmada durum çalışması deseni kullanılmıştır. Çalışma grubu, amaçlı örnekleme yöntemlerinden kolay ulaşılabilir durum örneklemesi yoluyla belirlenmiş olup Recep Tayyip Erdoğan Üniversitesi Türkçe Öğretmenliği Bölümü 3. sınıfta öğrenim gören 35 öğretmen adayından oluşmaktadır. Öğretmen adaylarının, dijital öyküleme sürecine ilişkin görüşlerini belirlemek için ise "Yarı Yapılandırılmış Görüşme Formu" ve dijital öykülere ilişkin algılarını tespit etmek için "Metafor Belirleme Formu" kullanılmıştır. Öğrenci görüşleri betimsel analiz yoluyla ve metaforlar ise içerik analizi yoluyla analiz edilmiştir. Araştırma sonucunda dijital öyküleme sürecinin, Türkçe öğretmeni adaylarının en çok yazma, teknoloji ve konuşma becerilerini geliştirdiği tespit edilmiştir. Araştırmada ayrıca Türkçe öğretmeni adaylarının dijital öyküleri eğlenceli, sürükleyici, yansıtıcı sanatsal bir araç olarak algıladıkları ortaya çıkmıştır.

Anahtar kelimeler: Türkçe öğretmeni adayları, dijital öyküleme, algı ve görüşler.

\footnotetext{
${ }^{*}$ This research was presented at UTEOK-2017 Conference.

** Corresponding Author: Assist. Prof. Dr., Süleyman Demirel University, Isparta, Turkey, veyseldemirer@sdu.edu.tr

${ }^{* * *}$ Assist. Prof. Dr., Recep Tayyip Erdoğan University, Rize, Turkey, yasemin.baki@erdogan.edu.tr
} 


\section{Giriş}

Uygarlığın ilk günlerinden bu yana, geleneksel öykü anlatımı bireylerin kendi toplumları içinde bilgilerini, inançlarını, değerlerini, geleneklerini, tarih ve kültürlerini birbirleriyle paylaşmasında ve gelecek nesillere aktarmasında kullanılan güçlü bir araç olmuştur (Smeda, Dakich, \& Sharda, 2012; Wang \& Zhan, 2010). Eğitimin eski bir biçimi olan öykü anlatımı okul öncesi dönemden yükseköğretime kadar öğretim stratejisi ve öğrenme aracı olarak kullanılmaktadır. Son zamanlarda öykülerin nasıl oluşturulduğu, hangi ortamlarda yayıldığı, izleyicilerin bu öykülere nasıl ulaştı̆̆ konusunda değişimler olmuştur. Özellikle bilişim teknolojilerinin kullanımının yaygınlaşması, çeşitli donanım ve yazılımların artması ile öykü anlatımı farklı biçimlere dönüşmeye başlamıştır (Van Gils, 2005). Bu dönüşüm ile öykü anlatımı sadece sözlü anlatım olmaktan çıkıp, çoklu ortamların kullanıldığı görsel ve işitsel öğeler bakımından zengin bir anlatıma dönüşmüştür (Alexander, 2011; Wang, \& Zhan, 2010). Dijital öyküleme olarak ifade edilen bu yeni yöntem dijital kamera, fotoğraf düzenleme yazılımları, yazarlık araçları ve Web 2.0 araçları gibi bilişim teknolojilerinin ortaya çıkması ve yaygınlaşması ile öykü anlatımında yeni bir pedagojik uğraş haline gelmiştir (Meadows, 2003). Özellikle akıllı cep telefonları ya da diğer dijital araçlar yardımıyla bireyler kendi kısa filmlerini oluşturmakta, bunları çeşitli yollarla başka kişilerle paylaşabilmektedir. $\mathrm{Bu}$ durum zamanla dijital öyküleme yönteminin eğitim ortamlarında da kullanılmasını artırmıştır (Demirer, 2013; Karakoyun, 2014; KocamanKaroğlu, 2015). İlgili alan yazında dijital öyküleme ile ilgili birçok tanım olmasına rağmen genel olarak, tümü öykü anlatma sanatını resim, ses, video gibi çeşitli çoklu ortam öğeleri ile bütünleştirme fikri etrafında birleşmektedir. Hemen hemen tüm dijital öyküler belirli bir konu ile ilgili bilginin sunulması için grafik, metin, seslendirme, video ve müzik gibi ögelerinin bir araya getirilmesiyle oluşturulmaktadır (Jakes \& Brennan, 2005; Robin, 2006). Dijital öyküleme, bireylere bir konu seçme, bu konu üzerinde biraz araştırma yapma, elde edilen bilgileri kullanarak bir metin yazma ve tümünü bir bütün olarak ilginç bir öykü haline getirme firsatı vermektedir. Daha sonra bu öykü ile grafik, resim, ses, metin, video ve müzik gibi değişik türdeki çoklu ortam öğeleri birleştirilerek video oluşturulup bilgisayarda ya da web ortamında izlenebilir hale gelmektedir (Robin, 2008).

Günümüzde dijital öyküleme yaklaşımı eğitim ortamlarında hem öğretmenler hem de öğrenciler için güçlü bir araç olmaya başlamıştır (Robin, 2006, 2008; Smeda, Dakich \& Sharda, 2010). Geleneksel öykü anlatımından farklı olarak dijital öyküleme çalışmaları öğrenenlere sadece dinleyici olmayı değil aynı zamanda öyküleri oluşturma ve etkileşim imkânı sunmaktadır (Dörner, Grimm \& Abawi, 2002). Birçok araştırma, dijital öyküleme çalışmalarının öğrencilerin öğrenme deneyimlerini kişiselleştirdiğini, derse yönelik ilgilerini ve motivasyonlarını arttırdığını, öğrenci işbirliğini kolaylaştırdığını, araştırma ve yaratıcı düşünme becerilerini geliştirdiğini, karmaşık konuların anlaşılmasına yardımcı olduğunu, bilgiyi daha uygun ve anlamlı bir şekilde sunmayı sağladığını göstermektedir (Demirer, 2013; Karataş, Bozkurt \& Hava, 2016; Kocaman-Karaoğlu, 2015; Miller, 2009; Robin, 2006, 2008; Sadik, 2008; Smeda ve diğerleri, 2010; Van Gils, 2005; Yang \& Wu, 2012). Dijital öyküleme ile ilgili yapılan çalışmalar, dijital öyküleme sürecine aktif olarak katılım gösteren öğrencilerin araştırma ve organizasyon becerilerinin geliştiğini ve anlatılan konuya ilgilerinin arttığını ortaya 
koymaktadır (Paull, 2002; Salpeter, 2005). Ayrıca dijital öyküleme çalışmalarına katılan öğrenciler fikirlerini düzenlemeyi, sorular sormayı, düşüncelerini açıklamayı ve sesli anlatım yapmayı öğrenirken diğer bireyleri dinleyerek ve onlarla etkileşim kurarak iletişim becerilerini geliştirebilmektedir (Robin, 2006). Araştırmalar dijital öyküleme çalışmaları yapan öğrencilerin problem çözme ve karar verme süreçlerine daha çok katıldıklarını ve sorumluluk aldıklarını göstermektedir (Chung, 2007; Sadik, 2008). Ayrıca dijital öyküleme çalışmaları öğrencilerin problemleri yenilikçi yollarla çözebilmesi için yaratıcılıklarının gelişmesinde yardımcı olmaktadır (Ohler, 2008). Dijital öyküleme öğrencilerin bilgi okuryazarlığı, görsel okuryazarlık, teknoloji okuryazarlığı ve medya okuryazarlığı gibi 21. yüzyıl becerilerini kazanmasında yardımcı olmaktadır (Jakes \& Brennan, 2005; Robin, 2006).

İlgili alan yazın incelendiğinde dijital öyküleme çalışmalarının öğrencilere birçok katkı sağladığı görülmektedir. Bunun yanında dijital öyküleme çalışmalarının dil öğrenme ve öğretme sürecine de katkıları olduğu da ortadadır (Norman, 2011; Sever, 2014). Özellikle yazma ve metin oluşturma becerisi yeni teknolojilerle birlikte yeniden şekillenmektedir (Baki, 2015). Teknolojideki değişim öğrencilerin metin algısını, yazılı metinlerden farklı duyuları uyaran dijital ortama doğru kaydırmıştır (Yee \& Hargis, 2012). Artık dil becerilerinin öğreniminde basılı metinler yerine çağın okuryazarlık becerilerini kapsayan zenginleştirilmiş metinlerin işe koşulduğu yöntemler önem kazanmaktadır. Bu bağlamda en eski ve güvenilir eğitim araçlarından biri olan öyküler, dijital çağda eğitici işlevlerini; resim, ses, müzik ve video gibi dijital içeriğin birleşiminden oluşan 2-3 dakikalık bir anlatı formu olan dijital öykülerle devam ettirmektedir (Chung, 2007; İnceelli, 2005). İlgili alan yazın dijital öyküleme çalışmalarının öğrencilerin okuma, yazma, konuşma, anlama ve dinleme becerilerini arttırdığını göstermektedir (Jakes, \& Brennan, 2005; Lee, 2014; Sadik, 2008; Tsou, Wang, \& Tzeng, 2006; Yang, \& Wu, 2012). Kurudayığlu ve Bal (2014) dijital öyküleme çalışmalarının, aktif bir sınıf ortamı oluşturduğu, öğrencilerin dil eğitimini desteklediği, dil hatalarını ve konuşmayı engelleyici yanlışlıkları düzeltmede etkili olduğunu ifade etmektedir. Dijital öyküleme öğrencilerin öyküleme sürecinde metinlerle olan etkileşimini arttırmakta, üst düzey düşünmelerine imkân sağlayarak daha derinlemesine ve anlamlandırarak okumalarına yardımcı olmaktadır. Ayrıca dijital öyküleme öğrencilere dili daha etkili kullanma becerisi kazandırarak yazma sürecinde daha rahat olmalarını sağlamaktadır (Ballast, Stephens, \& Radcliffe, 2008; Lee, 2014; Miller, 2009). Gakhar ve Thompson'a (2007) göre dijital öyküleme öğrencilere gerçekçi eserler tasarlama ve oluşturma sürecinde düşüncelerini tutarlı bir şekilde organize etme ve yaratıcı bir şekilde yazma firsatı sağlamaktadır. Birçok araştırma dijital öykülemenin öğrencilerin yazma becerilerini geliştirmede olumlu etkisini göstermektedir (Baki 2015; Baki, \& Feyzioğlu, 2017; Ballast ve diğerleri, 2008; Çıralı, 2014; Gakhar, \& Thompson, 2007).

Temel dil becerilerinin geliştirilmesinin amaçlandığg Türkçe öğretiminde, öğrenme-öğretme sürecinin zenginleştirmesinde teknolojinin sunduğu faklı yaklaşım ve modellere ilişkin etkinliklere sahip özellikleriyle dijital öyküleme yönteminin önemli işlevler üstleneceği düşünülmektedir (Baki, 2015). İlgili alan yazın incelendiğinde dijital öyküleme ile ilgili farklı branşlardan öğretmen adayları ile birçok çalışmanın yapıldığı görülmektedir (Condy, Chigona, Gachago, \& Ivala, 2012; Haşlaman, 2017; Karakoyun \& Kuzu, 2016; Karataş ve diğerleri, 2016; Kocaman-Karoglu, 2014; 
Özpinar, 2017; Sancar-Tokmak, Surmeli, \& Ozgelen, 2014; Tatlı \& Bayramoğlu, 2015; Uslupehlivan, Erden, \& Cebesoy, 2017). Bu çalışmalarda genel olarak öğretmen adayları dijital öykülerin öğrenme-öğretme sürecinde aktif olarak kullanılabileceğini (Uslupehlivan ve diğerleri, 2017), dijital öykülemenin öğretim sürecinde kullanılmasının; aktif katılım, başarı, motivasyon ve yaratıcılık gibi pek çok açıdan eğitsel avantajının olduğunu (Karataş ve diğerleri, 2016; Özpinar, 2017) dijital öykü anlatımı sayesinde teknolojik becerilerinin arttığını (Condy ve diğerleri, 2012; Heo, 2009) ifade etmişlerdir. Türkçe öğretiminde ise dijital öyküleme çalışmaları ile ilgili ortaokul düzeyinde çalışmalara rastlanmaktadır (Baki, 2015; Baki \& Feyzioğlu, 2017; Özerbaş \& Öztürk, 2017; Yılmaz, Üstündağ, Güneş \& Çalışkan, 2017). Duran ve Özen (2017) ise dijital öykülerin Türkçe öğretiminde kullanımına yönelik alan yazın taraması yapmışlardır. Ancak alan yazın incelendiğinde Türkçe öğretimi ile ilgili yeteri kadar çalışma yapılmadığı, ülkemizde de özellikle Türkçe öğretmen adayları ile gerçekleştirilen çalışmalara ihtiyaç duyulduğu açıtır. Bu bağlamda araştırmanın amacı Türkçe öğretmeni adaylarının dijital öyküleme çalışmalarından elde ettikleri deneyimler 1şı̆̆ında Türkçe öğretiminde dijital öyküleme sürecine yönelik görüşlerini ve dijital öyküleme kavramına yönelik algılarını ortaya koymaktır. Bu amaçlar doğrultusunda aşağıdaki sorulara yanıt aranmıştır:

1. Türkçe öğretmeni adaylarının dijital öyküleme sürecine ilişkin görüşleri nelerdir ve bu görüşlerin cinsiyete göre dağılımı nasıldır?

2. Türkçe öğretmeni adaylarının dijital öykü kavramına ilişkin algıları cinsiyete göre hangi temalar altında toplanabilir?

\section{Yöntem}

\section{Araştırmanın Modeli}

$\mathrm{Bu}$ araştırmada Türkçe öğretmeni adaylarının dijital öyküleme sürecine ilişkin görüşleri ve algılarını tespit etmek amacıyla bir durum hakkında çoklu bilgi kaynaklarıyla detaylı ve derinlemesine bilgi toplamasını ve durumun en ince ayrıntılarıyla tanımlamasını sağlayan durum çalışması deseni kullanılmıştır. Bu desende, değişkenler arasındaki sebep-sonuç ilişkileri, genelleme yapılmadan mevcut durumdan bir kesit alarak durum ayrıntılı bir şekilde yansıtılır (Creswell, 2012).

\section{Çalışma Grubu}

Araştırmanın çalışma grubu, amaçlı örnekleme yöntemlerinden kolay ulaşılabilir durum örneklemesi yoluyla belirlenmiştir (Yıldırım \& Şimşek, 2013). Katılımcılar 2015-2016 akademik yılı güz döneminde Recep Tayyip Erdoğan Üniversitesi Türkçe Öğretmenliği Bölümü 3. sınıfta öğrenim gören 14'ü (\%40) erkek, 21'i (\%60) kadın olmak üzere toplam 35 öğretmen adayından oluşmaktadır. Araştırma sürecine dâhil edilen öğretmen adaylarının Öğretim Teknolojileri ve Materyal Tasarımı dersini almış olmaları ön koşul olarak kabul edilmiştir. Bu şartları sağlayan öğretmen adaylarının aldıkları eğitim sebebiyle teknolojik olarak gerekli alt yapı bilgisine sahip oldukları varsayılmıştır. 


\section{Veri Toplama Araçları}

$\mathrm{Bu}$ araştırmada, Türkçe öğretmeni adaylarının dijital öyküleme sürecine ilişkin görüşlerini tespit etmek amacıyla "Yarı Yapılandırılmış Görüşme Formu (YYGF)", dijital öykü kavramına ilişkin algılarını tespit etmek amacıyla ise Metafor Belirleme Formu (MBF) kullanılmıştır. Araştırmacılar tarafından hazırlanan YYGF ile katılımcıların fikirlerini daha derinlemesine açıklaması, yanlış anlamaların azaltılması, bireyselliğin korunması ve durumun katılımcının bakış açısıyla değerlendirmesi amaçlanmıştır (Cohen, Manion, \& Morrison, 2011). Katılımcılarla belli bir forma dayalı olarak yapılan bu görüşme türüyle daha sistematik ve karşılaştırılabilir bilgi elde edilirken araştırma problemiyle ilgili istenen boyutların güvence altına alınması amaçlanmıştır (Patton, 2002). Bu formun hazırlanmasında ilgili alan yazın taramasının ardından dört açık uçlu sorudan oluşan görüşme soruları hazırlanmıştır. Yarı yapılandırılmış görüşme formunda katılımcılara şu sorular yöneltilmiştir:

1. Dijital öyküleme sürecinin hangi becerilerinizi geliştirdiğini düşünüyorsunuz? Niçin?

2. Dijital öyküleme sürecinin en beğendiğiniz aşamaları nelerdir?

3. Derslerinizde dijital öyküleri mi yoksa geleneksel öykü türünü mü tercih edersiniz? Niçin?

4. Dijital öyküler Türkçe dersine katkı sağlayacak uygun bir araç mıdır? Niçin?

Öğretmen adaylarının dijital öykülere ilişkin algılarını tespit etmek amacıyla, araştırmacılar tarafindan hazırlanan MBF'nin hazırlanmasında alan yazında metaforların bir araç olarak kullanıldığg araştırmalar (Saban, 2008; Sevim, Veyis \& Kınay, 2012) incelenmiştir. $\mathrm{Bu}$ araştırmalardan hareketle oluşturulan formun giriş bölümünde "metafor" kavramına ilişkin kısa bir açıklama ve metafor örneklerine yer verilmiş, araştırmanın amacı açık bir şekilde ortaya konulmuştur. Formun ikinci bölümünde ise katılımcıların “dijital öykü” kavramına ilişkin algılarını tespit etmek için "Dijital öykü .... gibidir. Çünkü ....” ifadesindeki boşlukları doldurmaları istenmiştir. Her bir öğretmen adayının beş metafor ve bu metaforlara ilişkin benzetme yönlerini ifade etmeleri istenmiştir.

Araştırmada kullanılan bu iki formun kapsam geçerliliği sağlamak amacıyla formlar öncelikle ölçme ve değerlendirmeden bir, Türkçe eğitiminden iki uzmanının görüşüne sunulmuş, uzmanların önerileri doğrultusunda formlara son şekli verilmiştir. Hazırlanan formlardaki soruları anlaşılabilirlik ve uygulanabilirlik açısından kontrol etmek amacıyla gönüllülük ilkesine bağlı olarak çalışma grubu dışında aynı düzeyde beş kişiden oluşan bir gruba pilot deneme yapılmış ve deneme sonucunda formlarla ilgili herhangi bir sorunla karşılaşılmamıştır (Glesne, 2011/2013). Bu aşamalardan sonra formlara son şekli verilmiştir.

\section{Verilerin Toplanması}

İki aşamadan oluşan araştırma süreci öncesinde katılımcılara dijital öykülemeye ilişkin beş ders saatini kapsayan bir seminer verilmiştir. Bu süreçte dijital öykülemenin uygulama aşamaları ve alan yazında yaygın olarak kullanılan Photo Story 3, Windows Live Movie Maker, resim düzenleme ve ses kaydı programlarının kullanımı uygulamalı olarak anlatılmış ve ardından araştırmacılar tarafından hazırlanan "Dijital Öykü El Kitabım” adlı kılavuz kitap öğretmen adaylarına verilmiştir. Seminerin ardından her 
öğretmen adayının istedikleri konuda iki haftalık süre içerisinde bir dijital öykü oluşturmaları istenmiştir. Bu öykülerin hazırlanmasına dijital öykü türlerinden "kişisel anlatı" türü tercih edilmiştir. Dijital öykülerin hazırlanmasının ardından her öğretmen adayı sınıf ortamında kendi dijital öyküsünü sunmuştur. Sonrasında öykülere ilişkin sınıf ortamında öğretim elemanı ve diğer adaylar tarafından Sarıca ve Usluel (2016) tarafından geliştirilen rubrik aracılığıyla değerlendirmeler yapılmıştır. İlgili değerlendirmeler ortalama 15 dakikalık süre içerisinde geçekleştirilmiş olup değerlendirme sonuçlarına göre her bir öğretmen adayı dijital öyküsüne son şeklini vermiştir.

Uygulama sürecinin ardından Türkçe öğretmeni adaylarının dijital öyküleme sürecine ilişkin görüşlerini tespit etmek amacıyla yarı yapılandırılmış görüşmeler yapılmıştır. Bu görüşmeler araştırmacı tarafından gerçekleştirilmiş olup bireysel görüşmeler yapılmış ve her bir görüşme yaklaşık olarak 30 dakika sürmüştür. $\mathrm{Bu}$ görüşmelerin ardından öğretmen adaylarına "Metafor Belirleme Formu" yazılı olarak sunulmuş ve forma ilişkin yapılan bilgilendirmenin ardından bu verilerin toplanması için öğretmen adaylarına 15 dakika süre verilmiştir.

\section{Verilerin Analizi ve Yorumlanması}

Araştırmada yarı yapılandırılmış görüşme formuyla elde edilen verilerin analizinde betimsel analiz yaklaşımı kullanılmıştır (Yıldırım \& Şimşek, 2013). Betimsel analiz yaklaşımında elde edilen veriler daha önceden belirlenen tema ve başlıklara göre özetlenmekte ve yorumlanmaktadır. Bu doğrultuda görüşme soruları birer tema olarak kabul edilmiş, bu temalar altında öğrenci görüşleri kodlanmış, frekans ve yüzde hesabı yapılarak tablo halinde sunulmuştur. Her temaya ilişkin kodlama işleminden sonra belirlenen kodlar birbirinden bağımsız iki uzmanın görüşüne sunulmuştur. Uzmanların ve araştırmacıların, kod ve tema listelerine ilişkin yaptıkları değerlendirmelerde görüş ayrılığına düşülen durumlarda diğer uzmanla yeniden kodlama yapılmış, görüş birliği ve görüş ayrılığı olan kodlamalar tespit edilmiştir. Araştırmacılar ve uzmanlar arasındaki görüş birliği ve ayrılıklarının, araştırmanın güvenirliği üzerindeki etkisi Miles ve Huberman'ın (1994) formülünden [Görüş birliği/(Görüş birliğii+Görüş ayrıllğı)x100] yararlanılarak yapılmış ve bu inceleme sonucunda araştırmacılar ve iki uzmanın görüşleri arasındaki uzlaşma (güvenirlik) \%90 ve \%94 olarak bulunmuştur.

Metaforların analizinde Saban'ın (2008) belirlediği; 1) adlandırma (kodlama) aşaması, 2) eleme ve arıtma aşaması, 3) derleme ve tema geliştirme aşaması, 4) geçerlik ve güvenirliği sağlama aşaması, 5) verilerin bilgisayar ortamına aktarılması, düzenlenmesi ve analizi aşamaları takip edilmiştir. Metaforlara ilişkin formlar; erkek öğretmen adayı (E), kadın öğretmen adayı $(\mathrm{K})$, sıra numarası $(1,2 \ldots)$ şeklinde kodlandırılmıştır. Ardından metaforlar benzer ve ortak nitelikleri bakımından sınıflandırılmış; kaynak ve hedef arasında ilişki olmayan, açıklaması olmayan metaforlar elenmiştir. Böylelikle 35 öğretmen adayının ürettiği 175 metafordan geçerli olarak kabul edilen 147 metafor; 1) metaforun konusu, 2) metaforun kaynağ1, 3) metaforun konusu ile kaynağı arasındaki ilişki açısından analiz edilerek ortak özelliklerine göre kategorileştirilmiştir (Saban, 2008). Verilerin analizinin güvenirliği sağlamak için analiz sonuçları, iki uzmanın görüşüne sunularak oluşturulan kavramsal kategoriler ve eşleştirildikleri metaforların listelerini incelemeleri istenmiştir. $\mathrm{Bu}$ inceleme sonucunda görüş birliği ve görüş ayrılığı olan değerlendirmeler belirlenerek 
görüş ayrılığına düşülen durumlarda diğer uzman ile ortak görüş alınarak yeniden değerlendirilmiştir. Bu eşleştirmeler, araştırmacıların eşleştirmeleriyle karşılaştırılmış, araştırmacıların ve uzmanların incelemesi sonucunda Miles ve Huberman'ın (1994) formülünden (Güvenirlik=Görüş birliği/[Görüş birliği+Görüş ayrılığ1]x100) yararlanılarak araştırmacılar ve uzmanlar arasındaki görüş birliği ve ayrılıklarının, araştırmanın güvenirliği üzerindeki etkisi incelenmiştir. Araştırmacılar ve uzmanların görüşleri arasındaki uzlaşma (güvenirlik) \%92 ve \%90 olarak bulunmuştur. Bu işlemin ardından veriler bilgisayar ortamına aktarılarak her bir kategoriyi temsil eden katılımcıların frekans (f) ve yüzde (\%) değerleri yorumlanmıştır.

\section{Bulgular}

Araştırmanın bu bölümünde, Türkçe öğretmeni adaylarıyla gerçekleştirilen görüşmeler ve dijital öykü kavramına ilişkin algılarını ortaya koyan metaforlara ait bulgular iki ana başlık altında sunulmuştur.

\section{Dijital Öykülere İlişkin Türkçe Öğretmeni Adaylarının Görüşleri}

Araştırmanın bu bölümünde Türkçe öğretmeni adaylarıyla gerçekleştirilen yarı yapılandırılmış görüşmelerden elde edilen bulgulara yer verilmiş ve bu bulgular katılımcıların görüşleriyle desteklenerek beş tema altında sunulmuştur.

Dijital öyküleme sürecinin beceri gelişimi üzerindeki etkileri. Türkçe öğretmeni adaylarının dijital öyküleme sürecinin beceri gelişimi üzerindeki etkilerine ilişkin görüşleri incelendiğinde; "yazma becerisi”, "okuma becerisi”, "teknolojik beceriler", "konuşma becerisi", "dinleme becerisi" ve "görsel beceri" olmak üzere altı kod ortaya çıkmıştır. Bu görüşlerden elde edilen bulguların frekans $(f)$ ve yüzde $(\%)$ değerleri Tablo 1'de verilmiştir.

Tablo 1

Dijital Öykülerin Beceri Gelişimi Üzerindeki Etkileri

\begin{tabular}{lcccccc}
\hline \multirow{2}{*}{ Kodlar } & \multicolumn{7}{c}{ Katıllimc1lar $^{2}$} \\
\cline { 2 - 8 } & \multicolumn{2}{c}{$\operatorname{Kadın}_{(21)}$} & \multicolumn{2}{c}{ Erkek $_{(14)}$} & \multicolumn{2}{c}{ Toplam $_{(35)}$} \\
\cline { 2 - 8 } & $f$ & $\%$ & $f$ & $\%$ & $f$ & $\%$ \\
\hline Yazma becerisi & 15 & 71.42 & 9 & 64.28 & 34 & 97.14 \\
Okuma becerisi & 8 & 38.09 & 2 & 14.28 & 10 & 28.57 \\
Konuşma becerisi & 12 & 57.14 & 8 & 57.14 & 20 & 57.14 \\
Dinleme becerisi & 6 & 28.57 & 4 & 19.04 & 10 & 28.57 \\
Görsel okuma/sunu becerisi & 10 & 47.61 & 10 & 71.42 & 20 & 57.14 \\
Teknolojik beceriler & 16 & 76.19 & 8 & 57.14 & 24 & 68.57 \\
\hline
\end{tabular}

Tablo 1'e göre kadın öğretmen adaylarının en çok teknolojik becerilerini (\%76.19) ve yazma becerilerini (\%71.42); erkek öğretmen adaylarının ise en çok görsel okuma/sunu becerileriyle (\%71.42) yazma becerilerini (\%64.28) geliştirdiği belirlenmiştir. Tüm katılımcılar açısından yapılan değerlendirmedeyse sırasıyla en çok 
yazma (\%97.14) ve teknolojik becerilerinin (\%68.57) geliştiği tespit edilmiştir. Katılımcıların, dijital öyküleme sürecinin beceri gelişimi üzerindeki etkilerine ilişkin görüşlerinden bazıları şu şekildedir:

Telaffuz, vurgu, tonlama becerilerimizin gelişmesini sağllyor (E, 4).

Konuşma, yazma, okuma ve bilgisayar becerilerini geliştirdiğini düşünüyorum $(E, 5)$.

Dijital öyküler aynı anda pek çok becerinin gelişimini sağllyor (E, 1).

Düz bir okumadan kurtulup vurgu ve tonlamaya dikkat etmeye başladım $(K, 26)$.

Etkileyici bir metin yazmak için hayal gücünü zorluyorsun (K, 27).

Dijital öyküleme sürecinin beğenilen aşamaları. Türkçe öğretmeni adaylarının dijital öyküleme sürecinin beğenilen aşamalarına ilişkin görüşleri incelendiğinde; "görselleştirme", "seslendirme”, "müzik seçimi”, “öykü yazma”, “öyküyü izleme”, "akış şeması" ve "dijital öykü oluşturma” olmak üzere yedi kod ortaya çıkmıştır. Bu görüşlerden elde edilen bulguların frekans (f) ve yüzde (\%) değerleri Tablo 2'de sunulmuştur.

Tablo 2

Dijital Öyküleme Sürecinin Beğenilen Aşamaları

\begin{tabular}{|c|c|c|c|c|c|c|}
\hline \multirow{3}{*}{ Kodlar } & \multicolumn{6}{|c|}{ Katılımcılar } \\
\hline & \multicolumn{2}{|c|}{$\operatorname{Kadin}_{(21)}$} & \multicolumn{2}{|c|}{ Erkek $_{(14)}$} & \multicolumn{2}{|c|}{ Toplam $_{(35)}$} \\
\hline & $f$ & $\%$ & $f$ & $\%$ & $f$ & $\%$ \\
\hline Görselleştirme & 7 & 33.33 & 5 & 35.71 & 12 & 34.28 \\
\hline Seslendirme & 12 & 57.14 & 2 & 14.28 & 14 & 40.00 \\
\hline Müzik seçme & 5 & 23.80 & 1 & 7.14 & 6 & 17.14 \\
\hline Öykü yazma & 4 & 19.04 & 2 & 14.28 & 6 & 17.14 \\
\hline Öyküyü izleme & 3 & 14.28 & 4 & 28.57 & 7 & 20.00 \\
\hline Akış şeması & 3 & 14.28 & 1 & 7.14 & 4 & 11.42 \\
\hline Dijital öykü oluşturma & 4 & 19.04 & 2 & 14.28 & 6 & 17.14 \\
\hline
\end{tabular}

Tablo 2'ye göre kadın öğretmen adayları dijital öyküleme sürecinin en çok seslendirme (\%57.14) ve görselleştirme (\%33.33) aşamasını; erkek öğretmen adayları ise görselleştirme $(\% 35.71)$ ve öyküyü izleme (\%28.57) aşamasını beğenmişlerdir. Bu kategori tüm öğretmen adayları açısından değerlendirildiğinde ise en çok beğenilen aşamanın seslendirme (\%40.00) ve görselleştirme (\%34.28) aşaması olduğu belirlenmiştir. Katılımcıların, dijital öyküleme sürecinin beğenilen aşamalarına ilişkin görüşlerinden bazıları şu şekildedir:

Görselleri aramak ve onları bulmak çok keyifliydi $(E, 1)$.

Yazdiğım öyküyü bire bir yaşadım (K, 7).

Müzik ekleyip öykümü izlediğim zaman en güzel kısmıydı (K, 11).

Gözümde canlandırdığım karakteri herkesin görmesini sağlayarak karakterlere hayat verdim gibi hissettim (E, 14). 
Öyküme ait görseller bulmak beni çok heyecanlandırdı (E, 19).

Seslendirme aşamasında dinleyiciyi istediğim gibi etkileyebilmek benim elimde (K, 27).

Türkçe dersinde dijital öykü ve öykü tercih sebepleri. Türkçe öğretmeni adaylarının, Türkçe dersinde dijital öykü ve öykü tercih sebeplerine ilişkin görüşleri incelendiğinde; “dijital öykü”, "geleneksel öykü” ve "içeriğe göre” olmak üzere üç kod ortaya çıkmıştır. $\mathrm{Bu}$ görüşlerden elde edilen bulguların frekans (f) ve yüzde (\%) değerleri Tablo 3 'te sunulmuştur.

Tablo 3

Türkçe Dersinde Dijital Öykü Tercihi

\begin{tabular}{lcccccc}
\hline & \multicolumn{6}{c}{ Katılımc1lar } \\
\cline { 2 - 7 } Kodlar & \multicolumn{2}{c}{ Kadın $_{(21)}$} & \multicolumn{2}{c}{ Erkek $_{(14)}$} & \multicolumn{2}{c}{ Toplam $_{(35)}$} \\
\cline { 2 - 7 } & $f$ & $\%$ & $f$ & $\%$ & $f$ & $\%$ \\
\hline Dijital öykü & 11 & 52.38 & 13 & 92.85 & 24 & 68.57 \\
Geleneksel öykü & 3 & 14.28 & 1 & 7.14 & 4 & 11.42 \\
İçeriğe göre & 7 & 33.33 & - & - & 7 & 20.00 \\
\hline
\end{tabular}

Tablo 3'e göre kadın öğretmen adaylarının \%52.38'i, erkek öğretmen adaylarının ise $\% 92.85$ 'i dijital öyküyü tercih etmiştir. Tüm öğretmen adaylarına ilişkin yapılan değerlendirmede ise katılımcıların \%68.57'si dijital öyküyü tercih edeceklerini belirtmişlerdir. Öğretmen adaylarının derslerde dijital öyküleri tercih etme sebepleri arasında "pek çok duyu organına hitap edişis", güdülenmeyi sağlaması", "çoklu beceri gelişimine etkisi" ve "eğlenceli ve dikkat çekici oluşu” gibi faktörlerin ön plana çıktığ 1 belirlenmiştir. Katılımcıların, Türkçe dersinde dijital öykü ve öykü tercihlerine ilişkin görüşlerinden bazıları şu şekildedir:

Öğrencinin pek çok duyu organına birden hitap eder (E, 1).

Dijital öyküyü tercih ederim çünkü öğrencinin konuşma, yazma, okuma, dinleme, bilgisayar becerileri gibi pek çok becerisini aynı anda geliştiriyor (E, 4).

Her ikisini de yerine göre kullanmayı tercih ederim (K, 8).

Öykü yazmayı severim çünkü kelimelerle oynamayı seviyorum (E, 14).

Dijital öyküler yazmaya güdülenmelerini sağlar $(K, 17)$.

Dijital öyküler daha eğlenceli ve daha dikkat çekici (E, 19).

Dijital öykülerin Türkçe dersinde kullanıma uygunluğu ve derse katkıları. Türkçe öğretmeni adaylarının, dijital öykülerin Türkçe dersinde kullanıma uygunluğuna ilişkin görüşleri incelendiğinde; "uygun" ve "kararsız" olmak üzere iki kod ortaya çıkmıştır. Bu görüşlerden elde edilen bulguların frekans (f) ve yüzde (\%) değerleri Tablo 4'te sunulmuştur.

Tablo 4'e göre kadın öğretmen adaylarının \%95.23'̈̈̈, erkek öğretmen adaylarının ise \%100'ü; dijital öykülerin Türkçe dersinde kullanıma uygun olduğunu belirtmişlerdir. Tüm öğretmen adayları açısından yapılan değerlendirmede ise 
katılımcıların nerdeyse tamamı (\%97.14) dijital öykülerin Türkçe dersine uygun olduğunu düşünürken sadece bir öğrenci ise bu konuda kararsız kalmıştır.

Tablo 4

Dijital Öykülerin Türkçe Dersinde Kullanıma Uygunluğu

\begin{tabular}{lllllll}
\hline \multirow{2}{*}{ Kodlar } & \multicolumn{5}{c}{ Katılımc1 } \\
\cline { 2 - 7 } & \multicolumn{2}{c}{ Kadın $_{(21)}$} & Erkek $_{(14)}$ & \multicolumn{2}{c}{ Toplam $_{(35)}$} \\
\cline { 2 - 7 } & $f$ & $\%$ & $f$ & $\%$ & $f$ & $\%$ \\
\hline Uygun & 20 & 95.23 & 14 & 100 & 34 & 97.14 \\
Karars1z & 1 & 4.76 & - & - & 1 & 2.87 \\
\hline
\end{tabular}

Katılımcıların, dijital öykülerin Türkçe dersine uygunluğuna ilişkin görüşlerinden bazıları şu şekildedir:

Yaratıcılığı tetikleyip yazmaya ittiği için uygundur $(E, 1)$.

Çünkü dersi daha uygun hale getirmektedir (K, 3).

Harika bir uygulama çocuklara öykü daha çok sevdirir (K, 20).

Türkçe öğretmeni adaylarının, dijital öykülerin Türkçe dersine sağlayacağı katkılara ilişkin görüşleri incelendiğinde; "beceri gelişimi”, "ilgi çekicilik", "eğlenceli" ve "kalıcılık" olmak üzere dört kod ortaya çıkmıştır. Bu görüşlerden elde edilen bulguların frekans (f) ve yüzde (\%) değerleri Tablo 5'te sunulmuştur.

Tablo 5

Dijital Öykülerin Türkçe Dersine Sağlayacă̆ı Katkılar

\begin{tabular}{lcccccc}
\hline \multirow{2}{*}{ Kodlar } & \multicolumn{5}{c}{ Katıllimcılar } \\
\cline { 2 - 7 } & \multicolumn{2}{c}{$\operatorname{Kadın}_{(21)}$} & \multicolumn{2}{c}{ Erkek $_{(14)}$} & Toplam $_{(35)}$ \\
\cline { 2 - 7 } & $f$ & $\%$ & $f$ & $\%$ & $f$ & $\%$ \\
\hline Beceri gelişimi & 17 & 80.95 & 14 & 100 & 31 & 88.57 \\
İlgi çekicilik & 16 & 76.19 & 6 & 42.85 & 22 & 62.85 \\
Eğlenceli oluş & 6 & 28.57 & 3 & 21.42 & 9 & 25.71 \\
Kalıcılık & 3 & 14.28 & 2 & 14.28 & 5 & 14.28 \\
\hline
\end{tabular}

Tablo 5'e göre kadın öğretmen adaylarının \%80.95'i, erkek öğretmen adaylarının ise \%100'ü ve tüm öğretmen adaylarının ise \%88.57'si dijital öyküleri beceri gelişimine katkı sağlayıcı olarak değerlendirmektedir. Bunun yanı sıra dijital öykülerin "ilgi çekicilik", "eğlenceli oluş" ve "kalıcılık” nitelikleriyle Türkçe dersine katkı sağlayacağını belirtmişlerdir. Katılımcıların, dijital öykülerin Türkçe dersine katkılarına ilişskin görüşlerinden bazıları şu şekildedir:

Ögrencileri öykü yazmaya teşvik edecektir $(K, 9)$.

Hayal gücünü geliştirerek zevk almasını sağlar (K, 9). 
Öyküyü kâğtttan okumak yerine resim ve müzikle zenginleştirmesini sağlar (K, 10).

Dijital öyküler, eğlenceli ve dikkat çekici $(E, 19)$.

Dijital öyküler ilgi çekici ve zengin bir içeriğe sahip $(K, 31)$.

\section{Öğretmen Adaylarının Dijital Öykülere İlişkin Ürettikleri Metaforlar}

Araştırmanın bu bölümünde Türkçe öğretmeni adaylarının dijital öykülere ilişkin ürettikleri metaforlara ait bulgulara yer verilmiştir. Bu metaforlar "zihinsel yapılandırma aracı", "eğlendirici bir araç", "sürükleyici bir araç”, "öğretici bir araç”, "yansıtıcı sanatsal bir araç" olmak üzere beş tema altında toplanmış olup bu sınıflandırma Şekil 1'de gösterilmiştir.

Şekil 1. Dijital Öykülere İlişkin Algılara Dair Temalar

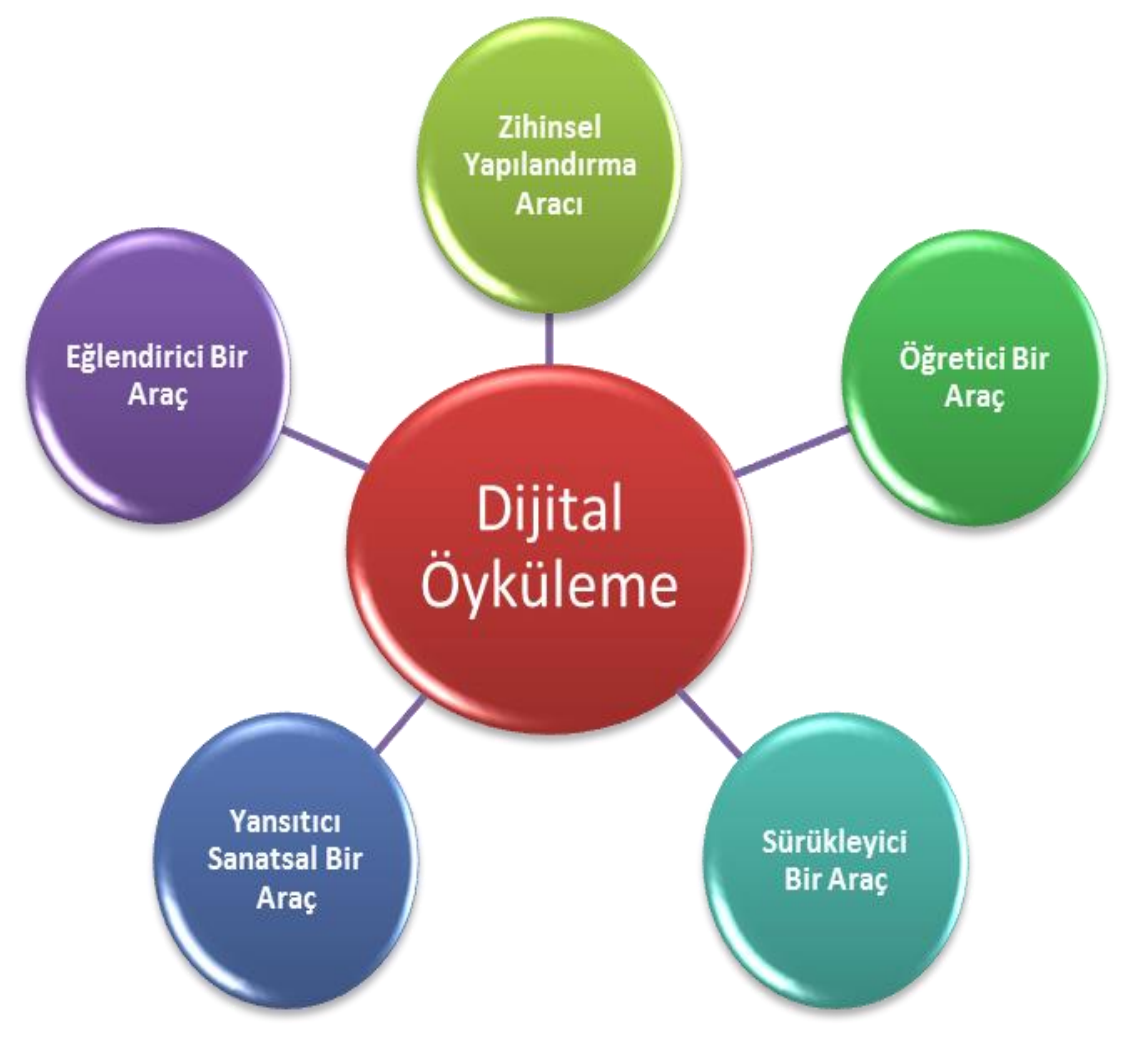

Araştırmada 35 katılımcıdan toplam 174 metafor elde edilmiş ancak 147 metafor araştırmaya dahil edilmiştir. 27 metafor ise metaforların gerekçelerinin sunulmamış olması sebebiyle araştırmanın kapsamı dışında bırakılmıştır. Araştırmaya dahil edilen metaforlar, toplandıkları temalar altında cinsiyete göre sınıflandırılmış olup bulgulara ait frekans (f) ve yüzde (\%) değerleri Tablo 6'da sunulmuştur. 
Tablo 6

Dijital Öykülere İlişkin Oluşturulan Metaforların Temalara Göre Dăğlımı

\begin{tabular}{lcccccc}
\hline & \multicolumn{5}{c}{ Temayı Temsil Eden Katılımcı } \\
\cline { 2 - 7 } Tema & \multicolumn{2}{c}{ Kadın $_{(21)}$} & & Erkek $_{(14)}$ & Toplam $_{(35)}$ \\
\cline { 2 - 7 } & $(f)$ & $\%$ & $(f)$ & $\%$ & $(f)$ & $\%$ \\
\hline Zihinsel yapılandırma aracı & 32 & 34.78 & 9 & 20.00 & 41 & 27.89 \\
Eğlendirici bir araç & 23 & 25.00 & 4 & 8.88 & 27 & 18.36 \\
Sürükleyici bir araç & 14 & 15.21 & 4 & 8.88 & 28 & 19.04 \\
Öğretici bir araç & 10 & 10.86 & 14 & 31.11 & 24 & 16.32 \\
Yansitıcı sanatsal bir araç & 13 & 14.13 & 14 & 31.11 & 27 & 18.36 \\
Toplam & 92 & 100 & 45 & 100 & 147 & 100
\end{tabular}

Tablo 6’ya göre kadın öğretmen adaylarının "zihinsel yapılandırma aracı" ( $f=32$, \%34.78), erkek öğretmen adaylarının ise "öğretici bir araç" $(f=14, \% 31.11)$ ve "yansitıcı sanatsal bir araç" ( $f=14, \% 31.11)$ temasında en çok metafor ürettikleri tespit edilmiştir. Tüm öğretmen adayları açısından yapılan değerlendirmede ise "zihinsel yapılandırma aracı" ( $f=41, \% 27.89)$ kategorisinde en çok metafor üretildiği belirlenmiştir. $\mathrm{Bu}$ metaforlara ilişkin temaların Türkçe öğretmen adaylarının cinsiyete göre dağılımlarına ilişkin bulgular tablolar halinde sunulmuştur. 
Tema 1: Zihni yapılandırma aracı olarak dijital öykü. Bu temada Türkçe öğretmeni adaylarının dijital öyküleri "Zihinsel Yapılandırma Aracı” olarak algılayıp bu algının üzerinden çeşitli metaforlar üretmişlerdir. Bu metaforların frekans $(f)$ ve yüzde (\%) değerleri Tablo 7'de sunulmuştur.

Tablo 7'ye göre bu temada dijital öyküleri kadın öğretmen adayları en çok "yapboz" ( $f=9, \% 28.15)$ metaforuyla ifade ederken erkek öğretmen adayları çeşitli metaforlar üretmişlerdir. Tüm öğretmen adayları açısından yapılan değerlendirmede ise dijital öyküler en çok "yapboz" ( $f=10, \% 24.39)$ ve ardından "gökkuşağı” ( $f=4, \% 9.75)$ metaforuyla ifade edilmiştir.

\section{Tablo 7}

Zihni Yapılandırma Aracı Temasına İlişkin Metaforlar

\begin{tabular}{|c|c|c|c|c|c|c|}
\hline \multirow{3}{*}{ Metafor } & \multicolumn{6}{|c|}{ Katılımcılar } \\
\hline & \multicolumn{2}{|c|}{$\operatorname{Kadin}_{(21)}$} & \multicolumn{2}{|c|}{ Erkek $_{(14)}$} & \multicolumn{2}{|c|}{ Toplam $_{(35)}$} \\
\hline & $f$ & $(\%)$ & $f$ & $(\%)$ & $f$ & $(\%)$ \\
\hline Yapboz & 9 & 28.15 & 1 & 11.11 & 10 & 24.39 \\
\hline Matruşka & 1 & 3.12 & - & 11.11 & 1 & 2.43 \\
\hline Domino taş1 & 2 & 6.25 & - & - & 2 & 4.87 \\
\hline Kahvaltı & - & - & 1 & 11.11 & 1 & 2.43 \\
\hline Kahve & - & - & 1 & - & 1 & 2.43 \\
\hline Işık & 1 & 3.12 & 1 & - & 2 & 4.87 \\
\hline Mevsim & 1 & 3.12 & - & - & 1 & 2.43 \\
\hline Deniz & 1 & 3.12 & - & - & 1 & 2.43 \\
\hline Gül & 1 & 3.12 & - & - & 1 & 2.43 \\
\hline Kum & 1 & 3.12 & - & - & 1 & 2.43 \\
\hline Gökkuşağ1 & 4 & 12.5 & - & - & 4 & 9.75 \\
\hline Pasta & 2 & 6.25 & - & - & 2 & 4.87 \\
\hline Kiyafet & 1 & 3.12 & - & - & 1 & 2.43 \\
\hline Beyin & - & - & 1 & 11.11 & 1 & 2.43 \\
\hline Hayal & 2 & 6.25 & - & - & 2 & 4.87 \\
\hline Düşünce & - & - & 1 & - & 1 & 2.43 \\
\hline Sentez & - & - & 1 & 11.11 & 1 & 2.43 \\
\hline Dünya & 1 & 3.12 & - & - & 1 & 2.43 \\
\hline Zihin görüntüsü & 1 & 3.12 & - & - & 1 & 2.43 \\
\hline Materyal & 1 & 3.12 & - & - & 1 & 2.43 \\
\hline Roman & 1 & 3.12 & - & - & 1 & 2.43 \\
\hline Anahtar & 1 & 3.12 & - & - & 1 & 2.43 \\
\hline Ev odas1 & 1 & 3.12 & - & - & 1 & 2.43 \\
\hline Emek & - & - & 1 & 11.11 & 1 & 2.43 \\
\hline Örgü çorap & 1 & 3.12 & - & - & 1 & 2.43 \\
\hline Besin & - & - & 1 & 11.11 & 1 & 2.43 \\
\hline Toplam & 32 & 100 & 9 & 100 & 42 & 100 \\
\hline
\end{tabular}


Tema 2: Eğlendirici bir araç olarak dijital öykü. Bu temada Türkçe öğretmeni adaylarının dijital öyküleri "Eğlendirici Bir Araç” olarak algılayıp bu algının üzerinden çeşitli metaforlar ürettikleri görülmektedir. $\mathrm{Bu}$ metaforların frekans (f) ve yüzde (\%) değerleri Tablo 8'de sunulmuştur.

Tablo 8

Ĕ̆lendirici Bir Araç Temasına İlişkin Metaforlar

\begin{tabular}{|c|c|c|c|c|c|c|}
\hline \multirow{3}{*}{ Metafor } & \multicolumn{6}{|c|}{ Katılımcılar } \\
\hline & \multicolumn{2}{|c|}{$\operatorname{Kadın}_{(21)}$} & \multicolumn{2}{|c|}{ Erkek $_{(14)}$} & \multicolumn{2}{|c|}{ Toplam $_{(35)}$} \\
\hline & $f$ & $(\%)$ & $f$ & $(\%)$ & $f$ & $\%)$ \\
\hline Oyun & 4 & 17.39 & - & - & 4 & 14.81 \\
\hline Şeker & 1 & 4.34 & - & - & 1 & 3.70 \\
\hline Şark1 & 3 & 13.04 & - & - & 3 & 11.11 \\
\hline Baklava & 1 & 4.34 & - & - & 1 & 3.70 \\
\hline Çocuk & 2 & 8.69 & 1 & 25.00 & 3 & 11.11 \\
\hline Çizgi film & 1 & 4.34 & - & - & 1 & 3.70 \\
\hline Film & 1 & 4.34 & 2 & 50.00 & 3 & 11.11 \\
\hline Susam & 1 & 4.34 & - & - & 1 & 3.70 \\
\hline Sevgi & 1 & 4.34 & - & - & 1 & 3.70 \\
\hline Çay & 2 & 8.69 & - & - & 2 & 7.40 \\
\hline Akarsu & 1 & 4.34 & - & - & 1 & 3.70 \\
\hline Oyun park1 & 1 & 4.34 & - & - & 1 & 3.70 \\
\hline Karikatür & 1 & 4.34 & - & - & 1 & 3.70 \\
\hline Kafka & 1 & 4.34 & - & - & 1 & 3.70 \\
\hline Hediye & 1 & 4.34 & - & - & 1 & 3.70 \\
\hline Hazine & - & - & 1 & 25.00 & 1 & 3.70 \\
\hline Masal & 1 & 4.34 & - & - & 1 & 3.70 \\
\hline Toplam & 23 & 100 & 4 & 100 & 27 & 100 \\
\hline
\end{tabular}

Tablo 8'e göre bu temada kadın öğretmen adayları dijital öyküleri en çok "oyun" ( $f=4, \% 17.39)$, erkek öğretmen adayları ise "film" $(f=2, \% 50.00)$ metaforuyla ifade etmişlerdir. Tüm öğretmen adayları tarafından ise dijital öyküler en çok "oyun" $(f=4$, $\% 14.81$ ) metaforuyla temsil edilmektedir. 
Tema 3: Sürükleyici bir araç olarak dijital öykü. Bu temada Türkçe öğretmeni adaylarının dijital öyküleri "Sürükleyici Bir Araç” olarak algılayıp bu algının üzerinden çeşitli metaforlar ürettikleri görülmektedir. Bu metaforların frekans $(f)$ ve yüzde (\%) değerleri Tablo 9'da sunulmuştur.

Tablo 9

Sürükleyici Bir Araç Temasına İlişkin Metaforlar

\begin{tabular}{|c|c|c|c|c|c|c|}
\hline \multirow{3}{*}{ Metafor } & \multicolumn{6}{|c|}{ Katılımcılar } \\
\hline & \multicolumn{2}{|c|}{$\operatorname{Kadın}_{(21)}$} & \multicolumn{2}{|c|}{$\operatorname{Erkek}_{(14)}$} & \multicolumn{2}{|c|}{ Toplam $_{(35)}$} \\
\hline & $f$ & $(\%)$ & $f$ & $(\%)$ & $f$ & $(\%)$ \\
\hline Deniz & 1 & 7.14 & 1 & 25.00 & 2 & 11.11 \\
\hline $\mathrm{Su}$ & 3 & 21.42 & 2 & 50.00 & 5 & 27.77 \\
\hline Rüya & 1 & 7.14 & - & - & 1 & 5.55 \\
\hline Gezinti & 1 & 7.14 & - & - & 1 & 5.55 \\
\hline Zaman makinesi & 1 & 7.14 & - & - & 1 & 5.55 \\
\hline İstasyon & 1 & 7.14 & - & - & 1 & 5.55 \\
\hline Jelibon & 1 & 7.14 & - & - & 1 & 5.55 \\
\hline At & 1 & 7.14 & - & - & 1 & 5.55 \\
\hline Koku & - & - & 1 & 25.00 & 1 & 5.55 \\
\hline Kuyu & 1 & 7.14 & - & - & 1 & 5.55 \\
\hline Duygu seli & 1 & 7.14 & - & - & 1 & 5.55 \\
\hline Doğa & 1 & 7.14 & - & - & 1 & 5.55 \\
\hline Bulut & 1 & 7.14 & - & - & 1 & 5.55 \\
\hline Toplam & 14 & 100 & 4 & 100 & 18 & 100 \\
\hline
\end{tabular}

Tablo 9'a göre bu temada hem kadın öğretmen adayları $(f=3, \% 21.42)$ hem de erkek öğretmen adayları $(f=2, \% 50.00)$ dijital öyküleri en çok ise "su" metaforuyla ifade etmişlerdir. Tüm öğretmen adayları tarafından da en çok "su” ( $f=5, \% 27.77)$ metaforu kullanılmıştır. 
Tema 4: Öğretici bir araç olarak dijital öykü. Bu temada Türkçe öğretmeni adaylarının dijital öyküleri "Öğretici Bir Araç" olarak algılayıp bu algının üzerinden çeşitli metaforlar ürettikleri görülmektedir. Bu metaforların frekans $(f)$ ve yüzde (\%) değerleri Tablo 10'da sunulmuştur.

Tablo 10

Öğretici Bir Araç Temasına İlişkin Metaforlar

\begin{tabular}{lcccccc}
\hline & \multicolumn{5}{c}{ Katıllimcilar } \\
\cline { 2 - 7 } Metafor & \multicolumn{2}{c}{ Kadın $_{(21)}$} & & Erkek $_{(14)}$ & \multicolumn{2}{c}{ Toplam $_{(35)}$} \\
\cline { 2 - 6 } Kitap & $f$ & $(\%)$ & $f$ & $(\%)$ & $f$ & $(\%)$ \\
Öğretmen & 2 & 20.00 & 1 & 7.14 & 3 & 12.5 \\
Hayat & 5 & 50.00 & - & - & 5 & 20.83 \\
Biz & - & - & 5 & 35.71 & 5 & 20.83 \\
Kalem & - & - & 1 & 7.14 & 1 & 4.16 \\
Kültür & - & - & 1 & 7.14 & 1 & 4.16 \\
Anne-baba & - & - & 1 & 7.14 & 1 & 4.16 \\
Arkadaş & 1 & 10.00 & - & - & 1 & 4.16 \\
İnsan & 1 & 10.00 & - & - & 1 & 4.16 \\
Konuşma & 1 & 10.00 & - & - & 1 & 4.16 \\
Yazma & - & - & 1 & 7.14 & 1 & 4.16 \\
Dinleme & - & - & 1 & 7.14 & 1 & 4.16 \\
Okuma & - & - & 1 & 7.14 & 1 & 4.16 \\
Sunucu & - & - & 1 & 7.14 & 1 & 4.16 \\
Toplam & - & - & 1 & 7.14 & 1 & 4.16 \\
\hline
\end{tabular}

Tablo 10'a göre bu temada kadın öğretmen adayları dijital öyküleri en çok "öğretmen" $(f=5, \% 50.00)$ metaforuyla, erkek öğretmen adaylar1 ise en çok "hayat" $(f=5, \% 35.71)$ metaforuyla ifade etmişlerdir. Tüm öğretmen adayları tarafindan da dijital öyküler en çok "öğretmen" $(f=5, \% 20.83)$ ve "hayat" $(f=5, \% 20.83)$ metaforuyla temsil edilmektedir. 
Tema 5: Yansıtıcı sanatsal bir araç olarak dijital öykü. Bu temada Türkçe öğretmeni adaylarının dijital öyküleri "Yansıtıcı Sanatsal Bir Araç" olarak algılayıp bu algının üzerinden çeşitli metaforlar ürettikleri görülmektedir. Bu metaforların frekans $(f)$ ve yüzde (\%) değerleri Tablo 11'de sunulmuştur.

Tablo 11'e göre bu temada kadın öğretmen adayları dijital öyküleri en çok "sanat" ( $f=3, \% 27.03)$, erkek öğretmen adayları ise en çok "ressamlık" ( $f=2, \% 14.28)$ metaforuyla ifade etmişlerdir. Tüm öğretmen adayları tarafından ise dijital öyküler en çok "sanat" ( $f=3, \% 11.11)$ ve "hayat" $(f=5, \% 11.11)$ metaforuyla temsil edilmektedir.

Tablo 11

Yansıtıcı Sanatsal Bir Araç Temasına İlişkin Metaforlar

\begin{tabular}{|c|c|c|c|c|c|c|}
\hline \multirow{3}{*}{ Metafor } & \multicolumn{6}{|c|}{ Katılımcilar } \\
\hline & \multicolumn{2}{|c|}{$\operatorname{Kadin}_{(21)}$} & \multicolumn{2}{|c|}{ Erkek $_{(14)}$} & \multicolumn{2}{|c|}{ Toplam $_{(35)}$} \\
\hline & $f$ & $(\%)$ & $f$ & $(\%)$ & $f$ & $(\%)$ \\
\hline Ayna & 1 & 7.69 & 1 & 7.14 & 2 & 7.40 \\
\hline Hayat & 2 & 15.38 & 1 & 7.14 & 3 & 11.11 \\
\hline Tiyatro & 1 & 7.69 & - & - & 1 & 3.70 \\
\hline Film & 1 & 7.69 & 1 & 7.14 & 2 & 7.40 \\
\hline Sihirli kutu & 1 & 7.69 & - & - & 1 & 3.70 \\
\hline Güneş & - & - & 1 & 7.14 & 1 & 3.70 \\
\hline Diksiyon kursu & 1 & 7.69 & - & - & 1 & 3.70 \\
\hline Pencere & - & - & 1 & 7.14 & 1 & 3.70 \\
\hline Rüya & 1 & 7.69 & - & - & 1 & 3.70 \\
\hline Deniz feneri & - & - & 1 & 7.14 & 1 & 3.70 \\
\hline Müze & - & - & 1 & 7.14 & 1 & 3.70 \\
\hline Birleşim & - & - & 1 & 7.14 & 1 & 3.70 \\
\hline Ressamlık & - & - & 2 & 14.28 & 2 & 7.40 \\
\hline Müzisyenlik & - & - & 1 & 7.14 & 1 & 3.70 \\
\hline Gözlemcilik & - & - & 1 & 7.14 & 1 & 3.70 \\
\hline Süsleme & - & - & 1 & 7.14 & 1 & 3.70 \\
\hline Mühendislik & - & - & 1 & 7.14 & 1 & 3.70 \\
\hline Sanat & 3 & 23.07 & - & - & 3 & 11.11 \\
\hline Şiir & 1 & 7.69 & - & - & 1 & 3.70 \\
\hline Sarmaşık & 1 & 7.69 & - & - & 1 & 3.70 \\
\hline Toplam & 13 & 100 & 14 & 100 & 27 & 100 \\
\hline
\end{tabular}

\section{Tartışma, Sonuç ve Öneriler}

Bu araştırmada, Türkçe öğretmeni adaylarının dijital öyküleme sürecine ilişkin görüşleri ve algıları incelenmiştir. Araştırma sonuçlarına göre dijital öykülemenin kadın öğretmen adaylarının en çok teknolojik becerilerini ve yazma becerilerini, erkek 
öğretmen adaylarının ise görsel okuma ve sunu ile yazma becerilerini geliştirdiği tespit edilmiştir. Etki sırasının değişmesine karşın yazma becerisi her iki kategoride de ortak olmakla birlikte tüm öğretmen adaylarına ilişkin değerlendirmede en çok yazma becerilerinin geliştiği sonucuna ulaşılmıştır. Öğretmen adayları yazma becerisine özellikle "hayal güçlerini geliştirme" ve "etkileyici bir metin oluşturma" açısından katkı sağladığını belirtmişlerdir. Benzer şekilde Xu, Park ve Baek (2011) dijital öykülemenin, öğrencilerin hayal güçlerini harekete geçirerek yazmaya teşvik ettiğini ortaya koymuştur. Dijital öykülemenin yazma sürecinde metin oluşturma, paragraf oluşturma (Gregory \& Steelman, 2009), yazının planlanması (Xu \& Ahn, 2011) ve kelime seçimi (Kervin \& Mantei, 2011) gibi etkilerle yazma becerisinin gelişiminde yapılandırıcı ve yaratıcı işlevler üstlendiği görülmektedir (Diaw, 2009). Çeşitli araştırmalarda dijital öykülemenin, yazma becerisinin gelişimine ve metin oluşturma sürecine olumlu katkılar sağladığı belirlenmiştir (Baki, 2015, Baki ve Feyzioğlu, 2017; Bogard, Mary \& McMackin, 2012; Verdugo \& Belmonte, 2007). Haşlaman'ın (2017) araştırmasında da dijital öykülerin öğretmen adaylarının öz düzenleme becerilerinin gelişimine olumlu katkılar sağladığı tespit edilmiştir. Yazma sürecinin de düşünceleri düzenleme becerilerinin açığa çıkışı olduğu düşünüldügünde bu araştırmadaki sonuçlarla örtüştüğü söylenebilir. $\mathrm{Bu}$ araştırmadaki bulgular bütün olarak değerlendirildiğinde ise Türkçe öğretmeni adaylarının dijital öykülemenin en çok yazma becerisi ve teknolojik becerilerin gelişimine katkı sağladığı yönünde görüş bildirdikleri görülmektedir. Bu süreçte özellikle teknolojik becerilerinin gelişmesinde geleneksel öykü yapısının teknoloji ile birleşerek dijitalleşmesinin etkisi ön plana çıkmaktadır (Foley, 2013). Araştırma sonucunda ayrıca dijital öykülemenin okuma, konuşma, dinleme, görsel okuma ve sunu becerilerinin gelişimine de katkı sağladığ görülmüştür. Yaratıcı bir dil öğrenme aracı olan dijital öykülemenin, dil eğitiminin amaçlandığı derslerde çeşitli dil becerilerinin gelişimine katkı sağladığına ilişkin sonuçlarla örtüşmektedir (Mathison \& Pohan, 2007; Norman, 2011; Oskoz \& Elola, 2016; Sylvester \& Greenidge, 2010). Değişen metin algısının yanı sıra dijital argümanların, öğrenme-öğretme sürecine uyumu sağlamasıyla (Kulla-Abbott \& Polman, 2008) temel dil becerileri ve teknolojik becerilerin eş güdümlü kullanımına olanak sağladığı söylenebilir.

Dijital öykülemenin en beğenilen aşamalarına ilişkin sonuçlar incelendiğinde öğretmen adaylarının en çok görselleştirme aşamasını beğendikleri görülmüşsür. Bu sonuçlarda özellikle görselleştirmenin ön plana çıkması öğrenme-öğretme sürecinde görsel okuryazarlığın etkisini ortaya koymaktadır. Görsel tasarımlar, nesnelerin sıradanlıktan sıyrılıp estetik değer kazanarak ve sanatsal bir niteliğe erişmesine katkı sağlamaktadır (Günay, 2008). Çünkü insan yaşadığı çevreyi, fiziksel ve ruhsal gereksinimleri doğrultusunda çağın estetik ve teknik değerleriyle yeniden inşa ederek üretir ve düzenlemektedir (Dursun \& Odabaş1, 2013; Parsa, 2007). Eğitici niteliğinin yanı sıra sanatsal bir işleve de sahip olan dijital öykülerin görselleştirme aşamasındaki amaç; öykü senaryosunun etkililiğini arttırmak için içeriği, uygun ve kaliteli görsellerle eşleştirmektir. Bu aşama, öğrencilerin sanata karşı duyarlılıklarının (Gordon, 2011), görsel farkındalıklarının (Botturi, Bramani \& Corbino, 2012) ve yaratıcılıklarının gelişimine katkı sağlamaktadır (Kervin \& Mantei, 2011). Çünkü görseller, bu süreçte dil bağlamı içerisinde gömülü olan anlamı açığa çıkarırken yapıların anlamlarını dinleyici ve öykü anlatıcısı için genişleterek öyküye olumlu katkı sağlar (Green, 2013). Öğretmen adaylarının, dijital öykülemede görselleştirme sürecini "keyifli”, "heyecan verici" ve 
"karakterlere hayat vermelerini sağladığı" için beğendikleri yönündeki görüşleri günümüz öğrencilerinin eğlence odaklı anlayışlarını (Bedir Erişti, 2016; Ciğerci, 2015; Şahin, 2009; Resnick, 2002) ve görsellerin önemini betimlemektedir. Dijital öykülemenin, görsel okuma ve sunu becerilerinin gelişimine sağladığı olumlu katkılar bu sonuçlarla örtüşmektedir (Fries-Gaither, 2010; Jakes \& Brennan, 2005; Karakoyun, 2014; Kılınç \& Yüzer, 2015; Menezes, 2012; Özer, 2016). Kellner'e (1998) göre de tek başına bağımsız bir ifade biçimi olan görsel okuryazarlık 21. yüzyıl becerilerini kapsayan diğer okuryazarlıkların hemen hepsiyle birlikte kullanılmaktadır.

Araştırmada öğretmen adaylarının büyük çoğunluğu dijital öykülemenin Türkçe dersine uygun olduğunu ve derslerinde geleneksel öykü yerine dijital öyküyü tercih edeceklerini belirtmişlerdir. Benzer şekilde alan yazındaki araştırmalar da dijital öykülemenin ders programlarıyla uyumlu bir şekilde yaygın olarak kullanıldığını ortaya koymaktadır (Borneman \& Gibson, 2011; Signes \& Speck, 2012; Kobayashi, 2012). Dijital öyküleme iyi bir planlama yapıldığında (Rossiter \& Garcia, 2010) Türkçe, sosyal bilgiler, hayat bilgisi, resim, müzik, matematik, fen ve teknoloji, edebiyat, coğrafya gibi birçok derste kullanılabilir (Demirer, 2013; Karakoyun, 2014; Sadik, 2008). Uslupehlivan ve arkadaşları (2017) tarafından öğretmen adaylarıyla gerçekleştirilen araştırmada da dijital öykülerin öğrenme-öğretme sürecinde aktif olarak kullanılabileceğini düşündükleri tespit edilmiş olup bu araştırmanın sonuçlarıyla örtüştüğü söylenebilir. $\mathrm{Bu}$ sonuçlardan hareketle dijital öykülerin derslerde kullanılabilecek bir araç olarak değerlendirildiği sonucuna ulaşılabilir. Bu araştırmada öğretmen adaylarının dijital öyküleri derslerde tercih etme sebepleri arasında "pek çok duyu organına hitap edişis”, güdülenmeyi sağlaması”, "çoklu beceri gelişimine etkisi”, "eğlenceli ve dikkat çekici oluşu” gibi faktörlerin ön plana çıktı̆̆ı belirlenmiştir. Bununla birlikte öğretmen adayları, dijital öykülerin "beceri gelişimi” açısından Türkçe öğretimine önemli katkılar sağlayacağını; bu katkıların dijital öykülerin "ilgi çekicilik", "eğlenceli olma", "hayal gücünü geliștirme", "kalıcılık" gibi özelliklerinden kaynaklandığını ifade etmişlerdir. Bir öğrenme-öğretme aracı olan dijital öykü, öğrencilerin cesaretlendirilmesinde (Sanchez, 2009), sınıf içerisinde uyumun sağlanmasında ve bilginin zenginleştirilmesinde önemli katkılar sağlamaktadır (Di Blas \& Paolini, 2013). Ayrıca bu süreçte motive edici bir etki oluşturarak (Turan \& Şeker, 2018; Robin \& McNeil, 2013) ders sürecini daha eğlenceli bir hale dönüştürmektedir (Kahraman, 2013). Böylelikle geleneksel yöntemin tekilliğine karşı çoklu alternatif sunma, öğrenme-öğretme sürecini bireyselleştirme, öğrenci katılımının aktif bir şekle dönüştürülmesine olanak sunmaktadır (Van Gils, 2005).

Türkçe öğretmeni adaylarının dijital öyküleri zihinsel yapılandırma aracı, eğlendirici, sürükleyici, öğretici ve yansıtıcı sanatsal bir araç olarak algıladıkları ve bu sürecin öğretmen adaylarında pozitif bir etki oluşturduğu söylenebilir. Bu algılayış erkek öğretmen adaylarında "öğretici” ve "yansıtıcı", kadın öğretmen adaylarında ise "zihinsel yapılandırma” boyutuyla açığa çıkarken "yapboz" ve "gökkuşağı" kavramlarının bu çağrışımda daha etkin olduğu görülmüştür. $\mathrm{Bu}$ kavramlarla dijital öykülemenin bütünleştirici ve düzenleyici (Haşlaman, 2017) yapısına vurgu yapıldığı söylenebilir. Benzer şekilde alan yazındaki araştırmalarda dijital öykülemenin proje tabanlı bir öğrenme olanağı sunduğu; öykü metni, ses, görüntü ve müziğin birbiriyle bütünleşerek anlamlı tek bir parçaya dönüştüğü yönündeki görüşlerle örtüşmektedir (Kearney, 2011; Kordaki \& Agelidou, 2010). Eğlendirici araç temasında dijital 
öykülerin zevkli bir araç olma özelliği ön plana çıkarılırken bu temada en çok "oyun" metaforunun kullanımı da günümüz neslinin eğlenceye dayalı öğrenme anlayışıyla örtüştügünü desteklemektedir. Sürükleyici araç temasında ise dijital öykülemenin akışkan bir süreç olduğu belirlenmiş olup ve bu algı da en çok "su" metaforuyla ortaya konulmuştur. Bu iki tema nitelik olarak dijital öykülerin sürükleyici ve eğlendirici özelliğini ön plana çıkarırken alan yazında dijital öykülerin eğlendirici niteliğe sahip olduğuna ilişkin sonuçlarla örtüşmektedir (Demirer, 2013; Kahraman, 2013; Karakoyun, 2014; Reinders, 2011; Rossiter \& Garcia, 2010). Ayrıca dijital öykülerin bu niteliği sınıfta da eğlenceli bir ortamın oluşmasını sağlayarak öğrenme-öğretme sürecine katkı sağlamaktadır (Yang \& Wu, 2012). Bu sonuçlardan hareketle dijital öykülere ilişkin alan yazındaki araştırmaların bu araştırmadaki öğretmen adaylarının algılarıyla örtüştüğü söylenebilir.

Öğretici araç temasında ise dijital öykülerin öğrenme sürecine olumlu katkısının “öğretmen” ve "hayat” metaforuyla özdeşleştirildiği tespit edilmiştir. Bu algı da dijital öykülerin öğrenen merkezli güçlü bir iletişim aracı işlevine sahip olduğuna ilişkin sonuçlarla örtüşmektedir (Condy ve diğerleri, 2012; Merritt, 2006). Dijital öykülerin öğretici işlevi öykü türünün gelişimsel özelliğiyle de paraleldir. Öykü türü, güzel sanatların bir dalı olan edebiyatın önemli araçlarından biridir. Bireyin kendini tanıma sürecinde eğitimin kullandığı en eski araçlardan biri olmasının yanı sıra sanatın hayatın bir aynası olması sebebiyle de "yansıtıcı bir araç" temasında dijital öykülerin yansıtıcı işlevi ön plana çıkarılmıştır. Bu temada "hayat", "sanat" ve "ressamlık" kavramlarının öne çıkışı da bu görüşü destekler niteliktedir. İnceelli (2005), dijital öyküleri geleneksel öykü anlatımının sanatsal formu olarak tanımlarken Chung (2007) ise estetik becerileri geliştiren sanatsal bir araç olarak tanımlamaktadır. Çünkü öğrenciler, dijital öykülerle anı keşfederken dijital, yaratıcı ve edebî yazma becerilerini kullanarak estetik bir ürün ortaya koymaktadır (Wake \& Modla, 2010). Öğrenci, müfredatla teknolojinin bütünleştirildiği eğlenceli ve yaratıcı bir ortamda kelime hazinesini aktif olarak kullanarak bilgi ve deneyimini aktarırken "yazar", "okuyucu”, "dinleyici”, "sanatçı", "düşünür", "tasarımcı", "yorumlayıcı" ve "iletişimci” gibi çeşitli roller de üstlenir (Chung, 2007; Foley, 2013). Bu roller çerçevesinde dijital ve çevrim içi araçlarla öğrencilerin yazılı bir metni yaratıcılıkları ve hayal güçleri çerçevesinde çok katmanlı bir metne dönüştürmelerine ilham kaynağı olmaktadır (Menezes, 2012; Tunç \& Karadağ, 2013). Bu yönüyle de estetik bir metin olan edebî metin çağın koşullarına göre farklı bir sanatsal role büründüğ̈ söylenebilir.

Öğretmen adaylarının dijital öykülere ilişkin algıları bütüncül olarak değerlendirildiğinde olumlu algılara sahip oldukları söylenebilir. Alan yazında da postmodern yaklaşımın çoğulcu anlayışıyla bağlamsallaştıran çok yönlü, pedagojik, sanatsal ve eğitici bir araç olarak tanımlanan (Bjørgen, 2010; More, 2008) dijital öyküler; görüntü, ses ve yazının birleşiminde oluşturduğu dijital simya etkisiyle gelenekseli modernle birleştirerek öğrenme-öğretme ortamlarına farklı bir soluk getirmektedir. Sonuç olarak dijital öyküler, modern eğitimin her alanında olduğu gibi dil eğitiminde de sahip olduğu bu üstünlüklerle olumlu katk1lar sunabilir. Bu sonuçlardan hareketle şu önerilerde bulunulabilir.

- Öğretmen düzeyinde gerçekleştirilecek proje ve atölye çalışmalarıyla dijital öyküler daha geniş kitlelere tanıtılabilir. 
- Bilgilendirici, öğretici ve tarihsel olayları anlatan dijital öykü türlerinden yararlanarak Türkçe derslerinde temalara uyumlu olacak çalışmalar yapılabilir.

- Dijital öyküleme süreci hizmet içi eğitimlerle öğretmenlere tanıtılarak ders içerisinde Türkçe öğretiminde kullanılan metin türleriyle müfredata uygun kullanımına dönük uygulamalar yapılabilir.

- Eğitim fakültelerinde lisans ve yüksek lisans dersleri kapsamında tanıtılıp yaygınlaştırılması sağlanabilir.

- $\mathrm{Bu}$ sonuçların etki ve uygulanabilirliğinin genişletilmesi için deneysel ve karma çalışmalarla süreç daha kapsamlı olarak değerlendirilebilir.

- Görselleştirme aşamasının ön plana çıkışının sebepleri ve bunun Türkçe öğretimine etkisi incelenebilir. 


\section{Summary}

Purpose and Significance: It is clear that the studies of digital storytelling make crucial contributions to the processes of learning and teaching language (Norman, 2011; Sever, 2014). Especially writing and composing a text skill is being reshaped along with the new technologies (Baki, 2015). Nowadays, the methods in which enriched texts covering literacy skills of the age are used instead of printed texts in language skills learning gain importance day by day. In this context, the educational function of the stories which are the oldest and reliable education tool are still used as 2-3 minutes long digital stories which are composed of the mixture of digital contents such as pictures, voice, music and video (Chung, 2007; İnceelli, 2005). The relevant literature shows that the studies of digital storytelling increase reading, writing, speaking, understanding and listening skills of the students (Jakes \& Brennan, 2005; Lee, 2014; Sadik, 2008; Tsou, Wang, \& Tzeng, 2006; Yang \& Wu, 2012). Moreover, the digital storytelling allows the students to feel more comfortable in the process of writing by gaining them the skill of using the language more effectively (Ballast et al., 2008; Lee, 2014; Miller, 2009). Research shows that the digital storytelling has positive influence on the students' development of writing skill (Baki 2015; Baki \& Feyzioglu, 2017; Ballast et al., 2008; Ciral1, 2014; Gakhar \& Thompson, 2007). Taking the relevant literature into consideration, it is thought that the digital storytelling methods are important in enriching learning-teaching process in Turkish Language education in which the basic language skills are aimed to be developed (Baki, 2015). Thus, it is significant to reveal effects of digital storytelling studies in Turkish Language learning. In this context, the purpose of this study is to reveal the Turkish Language preservice teachers' opinions about the digital storytelling process and their perceptions of the digital storytelling concept in the light of their experiences obtained from the digital storytelling studies.

Methods: The case study method has been used in the study. The study group, which has been determined through the convenient sampling is composed of 35 preservice teachers of Recep Tayyip Erdogan University who are the 3rd grade students of the Department of Turkish Teaching. While the "Semi-Structured Interview Form" is used to determine opinions of preservice teachers about digital storytelling process, "Metaphor Determination Form" is used to identify their perceptions about digital storytelling. Firstly, the participants were given a seminar which takes five course hours during the study which is composed of two stages. After the seminar, the preservice teachers created a digital storytelling and these stories were evaluated through some presentations. After this event, semi-structured interviews were done to learn opinions of the Turkish Language preservice teachers about digital storytelling. The descriptive analysis was conducted to analyze the data which was obtained thanks to the semistructured interview form (Yildirim \& Simsek, 2013). In addition, metaphors were analyzed by content analysis. The stages of 1) naming (coding), 2) elimination and purification, 3) compilation and development of categories, 4) validity and reliability, 5) computerizing and arranging the data which were stated by Saban (2008) were followed in the analysis of metaphor.

Results: Turkish Language preservice teachers have stated that the digital storytelling process develops "writing”, "reading", "using computer", "speaking”, "listening" and 
"visual" skills. In the digital storytelling process, it is emerged that they have most liked the stages of "visualization", "vocalization", "music selection", "story writing", "watching story", "flow chart" and "creating digital story". 52.38\% of the female preservice teachers and $92.85 \%$ of the male preservice teachers have chosen digital storytelling in the Turkish course. $68.57 \%$ of all the preservice teachers have stated they would prefer digital storytelling. $95.23 \%$ of the female preservice teachers and $100 \%$ of the male preservice teachers have said that the digital storytelling is suitable for Turkish language courses. They have added that the digital storytelling would make some contributions such as "development of skill", "attraction", "fun" and "permanence". The findings about the metaphors that Turkish language preservice teachers created about digital storytelling have been stated in the study. These metaphors have been collected under five conceptual categories which are "mental construction tool", "an entertaining tool", "a gripping tool", "a teaching tool" and "a reflective art tool".

Discussion and Conclusions: It is determined that while the storytelling develops technological skills of female preservice teachers, it develops visual reading, presentation and writing skills of the male preservice teachers in the study. The assessment of all preservice teachers has concluded that their most developed skill is writing. Xu, Park and Baek (2011) have stated that the digital storytelling encourages the students to write by stimulating their imagination. It seems that digital storytelling has constructive and creative functions (Diaw, 2009) in the development of writing skills with effects such as text creation, paragraph building (Gregory \& Steelman, 2009), writing planning (Xu \& Ahn, 2011) and word choice (Kervin \& Mantei, 2011). It is effective that the structure of traditional story is digitalized by combining with technology particularly in the development of technological skills (Foley, 2013). As a result of the study, it is seen that the digital storytelling contributes to the development of reading, speaking, listening, visual reading and presentation skills. These results overlap with the results which show that the digital storytelling contributes to various language skills in the language education (Mathison \& Pohan, 2007; Norman, 2011; Oskoz \& Elola, 2016; Sylvester \& Greenidge, 2010).

It is seen that while the female preservice teachers like the most vocalization and visualization in the digital storytelling process, the male preservice teachers like the most visualization and all the teachers like the most visualization stage. The fact that visualization comes to the forefront in these results reveals the impact of visual literacy during learning-teaching process. The aim in the visualization of digital storytelling stage which has also an artistic function is to match the content with suitable and qualified visuals to increase effectiveness of story script. This stage contributes to the development of students' sensibilities towards art (Gordon, 2011), visual awareness (Botturi, Bramani, \& Corbino, 2012) and their creativity (Kervin \& Mantei, 2011). The fact that the digital storytelling contributes to visual reading and presentation skills coincides with the results (Fries-Gaither, 2010; Jakes \& Brennan, 2005; Karakoyun, 2014; Menezes, 2012).

The majority of Turkish language preservice teachers have said that the digital storytelling is suitable for Turkish courses and they prefer digital storytelling rather than traditional stories in the study. Similarly, the studies in the literature reveal that the digital storytelling is widely used in accordance with the curriculum (Borneman \& 
Gibson, 2011; Signes \& Speck, 2012; Kobayashi, 2012). On the other hand, the preservice teachers have expressed that digital storytelling would make significant contributes to Turkish learning in terms of "development of skill" and these contributions originate from "attraction", "fun" and "permanence" characteristics of digital storytelling. The digital storytelling which is a learning-teaching tool encourages the students in the class environment (Sanchez, 2009), contributes to their motivation, orientation in the class and enrichment of information (Di Blas \& Paolini, 2013). Furthermore, it produces an effect motivating (Robin \& McNeil, 2013) and makes the course more entertaining (Kahraman, 2013).

It can be said that Turkish language preservice teachers perceive digital stories as a configuring mind, amusing, gripping, teaching and reflecting tool which is artistic and this process has a positive influence on preservice teachers. While this perception is seen in the male preservice teachers as "teaching" and "reflecting" dimensions, it is seen in the female ones as "configuring mind" dimension. Therefore, the holistic structure of the digital storytelling is stressed. In a similar way, the studies in the literature overlap with the fact that the digital storytelling has a learning possibility which is project-based and it is created by integrating story script, voice, image and music (Kearney, 2011; Kordaki \& Agelidou, 2010). While the amusing feature of digital storytelling comes to the forefront in the amusing tool category, the "game" metaphor draws attention in this category. They define the digital storytelling as a fluid process and use the "water" metaphor to reveal this in the gripping tool category. This result overlaps with the results showing amusing feature of digital stories in the literature (Demirer, 2013; Karakoyun, 2014; Reinders, 2011; Rossiter \& Garcia, 2010). It is detected that the positive contrib "life" metaphors in the teaching tool category. This perception overlaps with the results showing that digital storytelling has a strong communication tool function which is learner-based (Condy et al., 2012; Merritt, 2006). In addition, the reflective function of digital storytelling has been brought to the foreground in the "reflective tool" category. The fact that "life", "art" and "painting" concepts come into prominence supports this view. While İnceelli (2005) defines digital storytelling as an artistic form of traditional stories Chung (2007) defines it as an artistic tool developing aesthetic skills. This is because, while the students discover the moment with digital stories, they create an aesthetic product by using their creative and literary writing skills (Wake \& Modla, 2010). Evaluating perceptions of the preservice teachers about digital storytelling overall, it can be said that they have positive perceptions. As a result, digital storytelling can contribute to the language education as each branch of modern education with its advantages.

\section{Kaynakça}


Alexander, B. (2011). The new digital storytelling: Creating narratives with new media. Santa Barbara, CA: Praeger.

Baki, Y. (2015). Dijital öykülerin altıncı sınıf ögrencilerinin yazma sürecine etkisi (Yayımlanmamış doktora tezi). Atatürk Üniversitesi, Erzurum.

Baki, Y., \& Feyzioğlu, N. (2017). Dijital öykülerin 6. sınıf öğrencilerinin öykü yazma becerilerine etkisi. International Online Journal of Educational Sciences, 9(3), 686-704.

Ballast, K., Stephens, L., \& Radcliffe, R. (2008). The effects of digital storytelling on sixth grade students' writing and their attitudes about writing. In K. McFerrin et al. (Eds.), Proceedings of Society for Information Technology and Teacher Education International Conference 2008 (pp. 875-879). Chesapeake, VA: AACE.

Bedir Erişti, S. D. (2016). Katılımcı tasarım temelli dijital öyküleme sürecinde ilköğretim öğrencilerinin yaratıcılık göstergeleri. Turkish Online Journal of Qualitative Inquiry, 7(4), 462-492.

Bjørgen, A. M. (2010). Boundary crossing and learning identities-digital storytelling in primary schools. International Journal of Media, Technology and Lifelong Learning, 6(2), 161-177.

Bogard, J. M., Mary C., \& McMackin, M. C. (2012). Combining traditional and new literacies in a 21st-century writing workshop. The Reading Teacher, 65(5), 313323.

Borneman, D., \& Gibson, K. (2011). Digital storytelling: Meeting standards across the curriculum in a WWII/Holocaust unit. School Library Monthly, 27(7), 16-17.

Botturi, L., Bramani, C., \& Corbino, S. (2012). Finding your voice through digital storytelling. TechTrends, 56(3), 10-11.

Chung, S. K. (2007). Art education technology: Digital storytelling. Art Education, 60(2), 17-22.

Ciğerci, F. M. (2015). Illkokul dördüncü sınıf Türkçe dersinde dinleme becerilerinin geliştirilmesinde dijital hikayelerin kullanılması (Yayımlanmamış doktora tezi). Anadolu Üniversitesi, Eğitim Bilimleri Enstitüsü, Eskişehir.

Cohen, L., Manion, L., \& Morrison, K. (2011). Research method in Education. London: Routledge.

Condy, J., Chigona, A., Gachago, D., \& Ivala, E. (2012). Pre-service students' perceptions and experiences of digital storytelling in diverse classrooms. The Turkish Online Journal of Educational Technology, 11(3), 278-285.

Creswell, J. W. (2012). Educational research. Boston: Pearson Education.

Çıralı, H. (2014). Dijital hikâye anlatımının görsel bellek ve yazma becerisi üzerine etkisi (Yayımlanmamış yüksek lisans tezi). Hacettepe Üniversitesi, Ankara

Demirer, V. (2013). İlköğretimde e-öyküleme kullanımı ve etkileri (Yayımlanmamış doktora tezi). Necmettin Erbakan Üniversitesi, Konya.

Diaw, P. W. (2009). Case study: The influence of storytelling as prewriting activity (in the writing process) on narrative writing in the child left behind learning environment (Unpublished doctoral dissertation). Saint Joseph's University, USA: Pennsylvania. 
Di Blas, N., \& Paolini, P. (2013). Beyond the school's boundaries: Policultura, a largescale digital storytelling initiative. Educational Technology \& Society, 16(1), 1527.

Dörner, R., Grimm, P., \& Abawi, D. F. (2002). Synergies between interactive training simulations and digital storytelling: a component-based framework. Computers \& Graphics, 26(1), 45-55.

Özen, N. E., \& Duran, E. (2017). Dijital öyküler ve Türkçe eğitiminde kullanımı. Avrasya Dil Eğitimi ve Araştırmaları Dergisi, 1(1), 76-105.

Dursun, Ö. Ö., \& Odabaş1, H. F. (2013). Çoklu ortam tasarımı. Ankara: PegemA Yayıncilık.

Fries-Gaither, J. (2010). Digital storytelling supports writing across content areas. Ohio Journal of English Language Arts, 50(1), 9-13.

Foley, L. M. (2013). Digital storytelling in primary-grade classrooms (Unpublished doctoral dissertation). University of Arizona State, USA.

Gakhar, S. \& Thompson, A. (2007). Digital storytelling: Engaging, communicating, and collaborating. In R. Carlsen et al. (Eds.), Proceedings of Society for Information Technology \& Teacher Education International Conference 2007 (pp. 607-612). Chesapeake, VA: AACE.

Glesne, C. (2013). Nitel araştırmaya giriş. (Çev. Ed. A. Ersoy ve P. Yalçınoğlu).

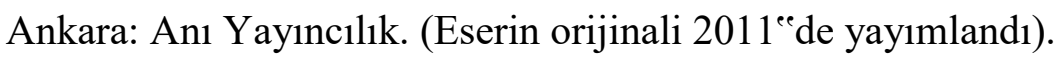

Gordon, C. (2011). Digital Storytelling in the classroom: Three case studies (Unpublished doctoral dissertation). University of Arizona State.

Gregory, K., \& Steelman, J. (2009, February). Digital storytelling: Powerful student engagement with multiple benefits. Paper presented at the annual meeting of the National Association of Developmental Education, Greensboro, NC.

Green, L. S. (2013). Language learning through a lens: The case for digital storytelling in the second language classroom. School Libraries Worldwide, 19(2), 23-36.

Günay, V. D. (2008). Görsel okuryazarlık ve imgenin anlamlandırılması. SDÜ ArteGüzel Sanatlar Fakültesi Sanat Dergisi, 1(1), 1-29.

Haşlaman, T. (2017). Özdüzenleyici öğrenmenin desteklenmesi: bir dijital öyküleme uygulaması. İlköğretim Online, 16(4), 1407-1424.

Heo, M. (2009). Digital storytelling: An empirical study of the impact of digital storytelling on preservice teachers' self efficacy and dispositions towards educational technology. Educational Multimedia and Hypermedia, 18(4), 405-428.

Jakes, D. S. \& Brennan, J. (2005). Capturing stories, capturing lives: An introduction to digital storytelling. 20.03.2011 tarihinde http://www.jakesonline.org/ dstory_ice.pdf adresinden erişilmiştir.

İnceelli, A. (2005). Dijital hikâye anlatımının bileșenleri. The Turkish Online Journal of Educational Technology, 4(3), 132-142.

Kahraman, Ö. (2013). Dijital hikayecilik metoduyla hazırlanan öğretim materyallerinin ögrenme döngüsü giriş aşamasında kullanılmasının fizik dersi başarısı ve motivasyonu düzeyine etkisi (Yayımlanmamış doktora tezi). Balıkesir Üniversitesi, Fen Bilimleri Enstitüsü, Balıkesir. 
Karakoyun, F. (2014). Çevrimiçi ortamda oluşturulan dijital öyküleme etkinliklerine ilişkin ögretmen adayları ve ilköğretim öğrencilerinin görüşlerinin incelenmesi (Yayınlanmamış doktora tezi). Anadolu Üniversitesi, Eğitim Bilimleri Enstitüsü, Eskişehir.

Karakoyun, F., \& Kuzu, A. (2016). The investigation of preservice teachers' and primary school students' views about online digital storytelling. European Journal of Contemporary Education, 15(1), 51-64.

Karataş, S., Bozkurt, Ş. B. ve Hava, K. (2016). Tarih öğretmeni adaylarının öğretim ortamlarında dijital hikâye anlatımı etkinliğinin kullanımına yönelik görüşleri. International Journal of Human Sciences, 13(1), 500-509.

Kearney, M. (2011). A learning design for student-generated digital storytelling. Learning, Media and Technology, 36(2), 169-188.

Kervin, L., \& Mantei, J. (2011). This is me: children teaching us about themselves through digital storytelling. Practically Primary, 16(1), 4-9.

Kılınç, A. G. H., \& Yüzer, T. V. (2015). Açık öğrenme sistemlerinde dijital öykülemeden faydalanmak. Eğitim ve Öğretim Araştırmaları Dergisi, 4(1), 243250.

Kobayashi, M. (2012). A digital storytelling project in a multicultural education class for pre-service teachers. Journal of Education for Teaching, 38(2), 215-219.

Kocaman-Karoglu, A.(2014). Personal voices in higher education: A digital storytelling experience for pre-service teachers. Education and Information Technologies, $1-16$.

Kocaman-Karoğlu, A. (2015). Öğretim sürecinde hikâye anlatmanın teknolojiyle değişen doğası: Dijital hikâye anlatımı. Eğitim Teknolojisi Kuram ve Uygulama, 5(2), 89-106.

Kordaki, M., \& Agelidou, E. (2010). A learning design-based environment for online, collaborative digital story telling: an example for environmental education. International Journal of Learning, 17(5), 94-105.

Kulla-Abbott, T., \& Polman, J. L. (2008). Engaging student voice and fulfilling curriculum goals with digital stories. THEN: Technology, Humanities, Education, Narrative, 5, 38-60.

Kurudayığlu, M., \& Bal, M. (2014). Ana dili eğitiminde dijital hikâye anlatımlarının kullanımı. Sakarya Üniversitesi Eğitim Fakültesi Dergisi, 28, 77-99.

Lee, L. (2014). Digital news stories: Building language learners' content knowledge and speaking skills. Foreign Language Annals, 47(2), 338-356.

Mathison, C., \& Pohan, C. A. (2007). Helping experienced and future teacher build professional interaction skill through the writing and reading of narratives. Issues in Teacher Education, 16(1), 61-73.

Meadows, D. (2003). Digital storytelling: Research-based practice in new media. Visual Communication, 2(2), 189-193.

Merritt, S. (2006). Digital storytelling: time, identity and morality in multimedia personal narratives of college writing students. International Journal of Learning, 13(8), 21-36. 
Menezes, H. (2012). Using digital storytelling to improve literacy skills. IADIS International Conference on Cognitionand Exploratory Learning in Digital Age. ERIC document.

Miller, E. A. (2009). Digital storytelling (Unpublished master's thesis). University of Northern Iowa.

Miles, M. B., \& Huberman, A. M. (1994). Qualitative data analysis: an expanded sourcebook. (2nd. Ed.). USA: SAGE Publication.

More, C. (2008). Digital stories targeting social skills for children with disabilities: Multidimensional learning. Intervention In School And Clinic, 43(3), 168-177.

Norman, A. (2011). Digital storytelling in second language learning: A qualitative study on students' reflections on potentials for learning (Unpublished doctoral dissertation). Norwegian University of Science and Technology, Norwegian.

Ohler, J. (2008). Digital storytelling in the classroom: New media pathways to literacy, learning, and creativity. Thousand Oaks, CA: Corwin Press.

Oskoz, A., \& Elola, I. (2016). Digital stories: Bringing multimodal texts to the Spanish writing classroom. ReCALL, 28(03), 326-342. doi: 10. 1017/S0958344016000094.

Özer, M. (2016). Dijital hikaye anlatımının kelime ögrenme ve akılda tutmadaki rolü: harran üniversitesi'nde bir durum çalışması (Yayımlanmamış yüksek lisans tezi). Çă̆ Üniversitesi, Sosyal Bilimler Enstitüsü, Mersin.

Özerbaş, M. A., \& Öztürk, Y. (2017). Türkçe dersinde dijital hikâye kullanımının akademik başarı, motivasyon ve kalıcılık üzerinde etkisi. TÜBAV Bilim, 10(2), 102-110.

Özpinar, İ. (2017). Matematik öğretmeni adaylarinin dijital öyküleme süreci ve dijital öykülerin öğretim ortamlarinda kullanimina yönelik görüşleri. Bartın Üniversitesi Ĕ̈itim Fakültesi Dergisi, 6(3), 1189-1210.

Parsa, A. F. (2007). İmgenin gücü ve görsel kültürün yükselişi. Fotografya Dergisi, 19, $1-10$.

Patton, M. Q. (2002). Qualitative research \& evaluation methods (3rd ed.). USA: SAGE Publication.

Paull, C. N. (2002). Self-perceptions and social connections: Empowerment through digital storytelling in Adult Education. Dissertation Abstracts International. (UMI No. 3063630).

Uslupehlivan, E., Erden, M. K., \& Cebesoy, Ü. B. (2017). Öğretmen adaylarının dijital öykü oluşturma deneyimleri. Uşak Üniversitesi Sosyal Bilimler Dergisi, Özel Sayı, $1-22$.

Reinders, H. (2011). Digital storytelling in the foreign language classroom. ELT World Online Blog. Retrieved November, 26, 1-9.

Resnick, M. (2002). Rethinking learning in the digital age. In the Global Information Technology Report: Readiness for the Networked World, 3, 32-36.

Robin, B. (2006). The educational uses of digital storytelling. In C. Crawford et al. (Eds.), Proceedings of Society for Information Technology \& Teacher Education International Conference 2006 (pp. 709-716). Chesapeake, VA: AACE. 
Robin, B. (2008). Digital storytelling: A powerful technology tool for the 21 st century classroom. Theory into Practice, 47(3), 220-228.

Robin, B., \& McNeil, S. G. (2013). The evolution of digital storytelling technologies: From PCs to iPads and e-Books. R. McBride and M. Searson, (Eds.). Proceedings of Society for Information Technology \& Teacher Education International Conference 2013 (s. 1712-1720). Chesapeake, VA: AACE.

Rossiter, M., \& Garcia, P. A. (2010). Digital storytelling: A new player on the narrative field. New Directions for Adult and Continuing Education, 126, 37-48.

Saban, A. (2008). İlköğretim I. kademe öğretmen ve öğrencilerinin bilgi kavramına ilişkin sahip oldukları zihinsel imgeler. İlkögretim Online, 7(2), 421-455.

Sadik, A. (2008). Digital storytelling: A meaningful technology-integrated approach for engaged student learning. Educational Technology Research and Development, 56(4), 487-506.

Salpeter, J. (2005). Telling Tales with Technology: Digital Storytelling Is a New Twist on the Ancient Art of the Oral Narrative. Technology \& Learning, 25(7), 18.

Sancar-Tokmak, H., Surmeli, H., \& Ozgelen, S. (2014). Preservice science teachers' perceptions of their TPACK development after creating digital stories. International Journal of Environmental and Science Education, 9(3), 247-264.

Sanchez, J. (2009). Pedagogical applications of second life. Library Technology Reports, 45(2), 21-28.

Sarıca, H. Ç., \& Usluel, Y. K. (2016). Eğitsel bağlamda dijital hikâye anlatımı: bir rubrik geliştirme çalışması. Eğitim Teknolojisi Kuram ve Uygulama, 6(2), 65-84.

Sever, T. (2014). An investigation into the impact of digital storytelling on the motivation level of students (Yayımlanmamış yüksek lisans tezi). Çanakkale Onsekiz Mart Üniversitesi, Çanakkale.

Sevim, O., Veyis, F., \& Kınay, N. (2012). Öğretmen adaylarının Türkçeyle ilgili algılarının metaforlar yoluyla belirlenmesi: Atatürk üniversitesi örneği. Cumhuriyet International Journal of Education, 1(1), 38-47.

Signes, C. G., \& Speck, B. P. (2012). Digital storytelling as a genre of mediatized selfrepresentations: an introduction. Digital Education Review, (22). [Online] ERIC 01.02. 2013 tarihinde erişilmiştir.

Smeda, N., Dakich, E., \& Sharda, N. (2010). Developing a framework for advancing elearning through digital storytelling, in IADIS International Conference e-learning 2010, Ed. Miguel Baptista Nunes and Maggie McPherson. IADIS International Conference, e-Learning 2010 Freiburg, Germany, 26-29 July 2010, 169-176.

Smeda, N., Dakich, E., \& Sharda, N. (2012). Digital storytelling with Web 2.0 tools for collaborative learning. In A. Okada, T. Connolly, \& P. Scott (eds.), Collaborative learning 2.0: Open educational resources (pp. 145-163). Hershey: IGI Global.

Sylvester, R., \& Greenidge, W. (2010). Digital storytelling: Extending the potential for struggling writers. The Reading Teacher Journal, 63(4), 284-295.

Şahin, M. C. (2009). Yeni binyılın öğrencilerinin özellikleri. Anadolu Üniversitesi Sosyal Bilimler Dergisi, 9(2), 155-172. 
Tatlı, Z., \& Bayramoğlu, A. (2015). Öğretmenlik uygulaması sürecinin dijital öyküler ile yansit1lmas1. Journal of Instructional Technologies \& Teacher Education, 4(2).

Tsou, W., Wang, W., \& Tzeng, Y. (2006). Applying a multimedia storytelling website in foreign language learning. Computers \& Education, 47(1), 17-28.

Tunç, Ö. A., \& Karadağ, E. (2013). Postmodernden oluşturmacılığa dijital öyküleme. Ĕgitim ve Öğretim Araştırmaları Dergisi, 2(4), 310-315.

Turan, T., \& Şeker, B. S. (2018). The effect of digital stories on fifth-grade students' motivation. Journal of Education and Future, (13), 65-78.

Van Gils, F. (2005). Potential applications of digital storytelling in education. In 3rd Twente Student Conference on IT, University of Twente, Faculty of Electrical Engineering, Mathematics and Computer Science, Enschede, February 17-18.

Verdugo, D. R, \& Belmonte, I. A. (2007). Using digital stories to improve listening comprehension with Spanish young learners of English. Language Learning \& Technology, 11(1), 87-101.

Xu, Y., \& Ahn, J. (2011). Effects of writing for digital storytelling on writing self efficacy and flow in virtual worlds. [Online]: ERIC 01.02. 2013 tarihinde erişilmiştir.

Xu, Y., Park, H., \& Baek, Y. (2011). A new approach toward digital storytelling: an activity focused on writing self-efficacy in a virtual learning environment. Educational Technology \& Society, 14(4), 181-191.

Wake, D. G., \& Modla, V. B. (2010). Language experience stories gone digital: Using digital stories with the LEA approach. Mentoring literacy professionals: continuing the spirit of CRA/ALER after, 50, 253-274.

Wang, S. \& Zhan, H. (2010). Enhancing teaching and learning with digital storytelling. International Journal of Information and Communication Technology Education (IJICTE), 6(2), 76-87.

Yang, Y. T. C. \& Wu, W. C. I. (2012). Digital storytelling for enhancing student academic achievement, critical thinking, and learning motivation. A year-long experimental study. Computers \& Education, 59(2), 339-352.

Yee, K., \& Hargis, J. (2012). Digital storytelling: kizoa, animoto, and photo story 3. Turkish Online Journal of Distance Education-TOJDE, 13(1), 13-17.

Yıldırım, A., \& Şimşek H. (2013). Sosyal bilimlerde nitel araştırma yöntemleri. Ankara: Seçkin Yayınları.

Yılmaz, Y., Üstündağ, M.T., Güneş, E., \& Çalışkan, G. (2017). Dijital hikayeleme yöntemi ile etkili Türkçe öğretimi. Eğitim Teknolojisi Kuram ve Uygulama, 7(2), 254-275.

This is an Open Access article distributed under the terms of the Creative CommonsAttributionNonCommercial-ShareAlike 4.0 International (CC BY-NC-SA 4.0). For further information, you can refer to https://creativecommons.org/licenses/by-nc-sa/4.0/ 